\title{
Water for Life: The Impact of the Privatization of Water Services on Child Mortality
}

\author{
Sebastian Galiani \\ Universidad de San Andres \\ Paul Gertler \\ University of California at Berkeley and NBER \\ and \\ Ernesto Schargrodsky ${ }^{*}$ \\ Universidad Torcuato Di Tella
}

January 6, 2003

\begin{abstract}
While most countries are committed to increasing access to safe water and thereby reducing child mortality, there is little consensus on how to actually improve water services. One important proposal under discussion is whether to privatize water provision. In the 1990s Argentina embarked on one of the largest privatization campaigns in the world including the privatization of local water companies covering approximately 30 percent of the country's municipalities. Using the variation in ownership of water provision across time and space generated by the privatization process, we find that child mortality fell 8 percent in the areas that privatized their water services; and that the effect was largest (26 percent) in the poorest areas. We check the robustness of these estimates using cause specific mortality. While privatization is associated with significant reductions in deaths from infectious and parasitic diseases, it is uncorrelated with deaths from causes unrelated to water conditions.
\end{abstract}

JEL: D60, H51, I10, I30, L33, O12

Keywords: privatization, child mortality, water provision, and poverty.

\footnotetext{
* Sebastian Galiani, Universidad de San Andres, Vito Dumas 284, (B1644BID) Victoria, Provincia de Buenos Aires, Argentina, Tel: (54-11) 4746-2608, sgaliani@udesa.edu.ar. Paul Gertler, Haas Business School, University of California at Berkeley, Berkeley, CA 94720-1900, US, Tel: (510) 642-1418, gertler@haas.berkeley.edu. Ernesto Schargrodsky, Universidad Torcuato Di Tella, Miñones 2177, (C1428ATG) Buenos Aires, Argentina, Tel: (54-11) 4784-0080, eschargr@utdt.edu. This paper has benefited from comments by Joshua Angrist, Alberto Chong, Jonathan Gruber, David Levine, Steve Levitt, Florencio Lopez-de-Silanes, Sebastian Martinez, Ted Miguel, Rohini Pande, Manisha Shah, Pablo Spiller and Maximo Torero. We are also grateful to Pablo Cafiero M.D., Liliana Clara M.D., and Enrique Calderon M.D. who provided expert information on water-related diseases in Argentina, and to Matias Cattaneo and Juan Pantano who provided excellent research assistance.
} 
At the 2000 Millennium Summit, member countries of the United Nations unanimously agreed on a set of eight goals to reduce poverty by 2015; among which are reducing child mortality by twothirds and cutting in half the number of households that do not have access to safe water. These two goals are interrelated in that clean water is critical to containing the spread of infectious and parasitic diseases. Indeed, each year more than 3 million children die from preventable waterrelated diseases (World Bank, 2002a), and a number of studies have found that access to safe water is associated with better child health (Merrick, 1985; Behrman and Wolfe, 1987; the Cebu Team, 1991; Esrey et al, 1991; Lavy et al, 1996; Lee et al, 1997; Jalan and Ravallion, 2002; inter alia).

While most countries have committed to increasing access to safe water, there is little consensus on how to actually achieve this goal. One proposal under consideration by many governments is to turn water provision over to a regulated private sector. Governments who want to privatize water systems are typically motivated by potential efficiency gains. They hope that these efficie ncy gains will be translated into expanded access and enhanced service quality, and thereby improve health outcomes. While there has been little privatization of water services (World Bank, 2002a), a number of authors have reported large gains in productivity and profitability associated with privatization in other sectors (Megginson et al, 1994; Barberis et al, 1996; Frydman et al, 1999; La Porta and Lopez-de-Silanes, 1999; inter alia).

In the water sector, however, it is not clear whether any efficiency gains from privatization would necessarily be translated into improved health outcomes or help to alleviate poverty. Indeed, recent public opinion polls and press articles report widespread discontent with privatization in general in Latin America (Finnegan, 2002; IDB, 2002; McKenzie and Mookerjee, 2002; Tagliabue, 2002). Private water companies may provide sub-optimal service quality levels because they fail to take into account the significant health externalities that are present in this industry (Shirley, 2000). In this case, privatization of water services may affect health outcomes negatively. In addition, privatization may hurt the poor through price increases, service payment 
enforcement, and investment only in lucrative high-income areas (Estache et al, 2001; Birdsall and Nellis, 2002). In this case, efficiency gains from privatization might be obtained at the cost of excluding the poor from access to water services, and thus health outcomes of the poor may actually deteriorate under privatization.

In this paper, we examine the impact of the privatization of water services on child mortality in Argentina. Our study focuses on young children because they are particularly vulnerable to water-related diseases due to weak body defenses, higher susceptibility, and greater exposure from inadequate knowledge of how to avoid risks (WHO, 2002a). There are two main disease transmission mechanisms generated by the lack of appropriate water systems: waterborne diseases that occur by drinking contaminated water, and water-washed diseases that occur when there is a lack of water and sanitation for household hygiene. Young children worldwide suffer from several deadly diseases that could easily be prevented through the interruption of these transmission mechanisms by access to safe and sufficient water supply and provision for the hygienic removal of sewage (WHO, 2000). For example, diarrhea alone accounts for approximately 15 percent of all child deaths worldwide (UNICEF, 2001). In Argentina, diarrhea, septicemia, and gastrointestinal infections are three of the top ten causes of death for children under five (Ministerio de Salud, 1999).

Our analysis takes advantage of the fact that local governments are responsible for delivering water services and only some municipalities privatized those services. Between 1991 and 1999, about 30 percent of municipalities covering approximately 60 percent of the population privatized their water services. This variation in ownership across time and space provides a potential instrument to identify the causal effect of privatization on child mortality.

A major methodological concern, however, is that local governments choose to privatize water services, and that choice may not be orthogonal to unobservable factors that also affect mortality. We address this concern in a number of ways that lead us to believe that the link between the privatization of water systems and child mortality is causal. 
In the end, despite the concerns about potential negative health effects, we find that the privatization of water services is actually associated with a reduction in child mortality of 8 percent. Moreover, we find that most of the reduction in mortality occurred in low-income areas (26 percent), where the network expansion was greatest. Finally, we check the robustness of these estimates using cause specific mortality. While privatization is associated with significant reductions in deaths from infectious and parasitic diseases, it is uncorrelated with deaths from causes unrelated to water conditions.

\section{THE ECONOMICS OF WATER SERVICE DELIVERY}

Water systems include both the supply of clean water and the treatment and removal of sewage. These services are a natural monopoly involving large fixed costs and significant economies of scale (Noll et al, 2000). ${ }^{1}$ There is typically little competition to a well functioning water system from alternative sources (Foster, 1999; Estache et al, 2001). The main alternative is household self-provision through pumped wells, rainwater catchments, cesspools, and septic tanks. Selfprovision suffers from low quality and high cost (Abdala and Spiller, 1999). Similarly, the sale of drinkable water from private vendors is substantially more costly and therefore does not present serious competition either. Finally, the average asset life of water systems' physical plant is very long and therefore impedes any potential dynamic competition.

The water sector is also characterized by the presence of significant externalities. Most water-related diseases are contagious. This generates positive externalities in the provision of clean water across society. Similarly, the proper elimination of sanitation residuals and treated industrial waste prevents negative externalities through the pollution of natural bodies of water and other natural resources.

\footnotetext{
${ }^{1}$ For example, fixed costs represent more than $80 \%$ of water service costs in the United Kingdom (Armstrong et al, 1994).
} 
Another special feature of water supply is that, as human life depends on access to drinkable water, the demand for water is perfectly price inelastic at survival levels. Of course, demand exhibits some price elasticity at levels for which water is used for other non-survival household and productive uses.

These features -natural monopoly, presence of significant externalities, and inelasticity of demand- have historically justified public intervention in the water sector. Most countries supply water services through the public sector, and private entry into water provision has been limited. However, there are growing calls to consider allowing a regulated private sector to deliver water services (World Bank, 2002a).

Private supply has the advantage of providing strong incentives for cost reductions and other productivity enhancements. In contrast, these incentives are weak under public ownership, where typically agents cannot reap the results of their effort and innovation. In fact, empirical evidence from several sectors strongly suggests that service quality, productivity and profitability rise significantly following privatization (Megginson et al, 1994; Barberis et al, 1996; Frydman et al, 1999; La Porta and Lopez-de-Silanes, 1999).

Nonetheless, the weak efficiency incentives in public firms might be tolerable when cost reductions by private suppliers come at the expense of undesirable quality deterioration or reductions in access by the poor. In particular, unregulated private providers may undersupply the socially optimal quality of water in the presence of externalities because they fail to take into account the marginal social benefits in their decisions. Similarly, private owners may exclude low-income households from the network by raising prices, strictly enforcing payment, and concentrating their investments in high-income areas.

However, the fear of quality deterioration or access exclusion can only be genuine when supply conditions are non-contractible (Shleifer, 1998). In the water industry, information asymmetries in service quality are relatively unimportant, and regulatory agencies can monitor 
water quality, pressure, repair delays, and shortages. Network expansions and universal coverage can also be enforced through regulation.

The arguments in favor of private provision are even stronger when we consider nonbenevolent governments. Politicians may use the control of state firms to channel benefits for themselves and their supporters (Shleifer and Vishny, 1994). Excess employment, corruption, subsidies, and pork barreling are typical of state owned enterprises (SOEs) around the world. As Shleifer (1998) explains it, state companies not only are unproductive because of the lack of managerial incentives, but also because inefficiency results from the political use of SOE resources.

Finally, the process of resource allocation within the aggregated public sector does not guarantee the assignment of funds to the most profitable projects. The chronic under-investment in physical capital that plagues many SOEs is aggravated for debt-ridden governments with large fiscal deficits. Privatization can significantly improve the access of firms to capital markets and therefore boost their ability to invest.

\section{THE ARGENTINE PRIVATIZATION PROGRAM}

The privatization of public water systems in Argentina represented a small part of a massive program that transferred almost all SOEs to private hands during the 1990s. The privatization process was, in turn, a part of a larger program of structural reform intended to revert decades of economic decline.

In the late 1980s Argentina was experiencing growing inflation driven in large part by printing money to finance huge fiscal deficits. The deficit averaged approximately $9 \%$ of GDP during the decade (Heymann and Navajas, 1989). While federal and provincial overspending generated the lion's share of these deficits, a non-trivial portion was due to significant SOE losses. By the end of the decade the ruling Radical government was unable to balance the budget. Further deficit spending could not be financed through printing money or new debt issues. In 
1989 the country entered a period of hyperinflation that lead the Radical government to resign six months before the official end of their administration.

The newly appointed Peronist government immediately launched an ambitious structural reform program designed to reduce the budget deficit, control inflation and put the country back on a positive growth path. The program consisted of financial and trade liberalization, a monetary currency board, the decentralization of health and educational services, the reform and privatization of the national pension system, the emancipation of the Central Bank, a general deregulation of economic activities, and the privatization of SOEs.

The privatizations were intended to reduce the budget deficit (Galiani and Petrecolla, 1996; Gerchunoff, 1992; Heymann and Kosacoff, 2000). The acquiring firms paid the government substantial sums for the privatized companies in the form of cash and Argentine external debt bonds. In addition to the revenues from privatization, the government no longer needed to cover SOE losses from the budget.

The privatization was also intended to reverse a long period of physical infrastructure neglect (Chisari et al, 1999). During the 1970s and 1980s there was little capital investment in most public utilities and indeed much of the physical infrastructure had seriously depreciated. After this long period of negative net investments, huge capital inflows were needed to improve both the quality and access to SOE services. While the public sector had no capacity to finance those capital investments, private firms generating positive cash-flows were able to obtain private financing. Indeed, the transfer of the SOEs to the private sector, mostly to large foreign companies, greatly improved the firms' investment and access to credit markets (Heymann and Kosacoff, 2000; Galiani et al, 2002). Most of the privatized firms sold equity and bonds in international capital markets.

Argentina implemented one of most ambitious privatization programs in the world. Table 1 summarizes the main federal privatizations, the income received from the sale of the companies, and the timing of privatization. The privatized SOEs were mainly large natural 
monopolies in sectors such as electricity, oil and natural gas, telecommunications, transportation, mail service and water systems. According to the official statistics (CEP, 1998), 154 privatization contracts were signed during the 1990s. The privatization revenues collected by the federal government reached more than 19 Billion US dollars. This figure understates the true amount of revenues obtained from privatization, as it does not include revenues from royalties received from SOEs that were privatized as concessions, and revenues from the privatization of provincial and local SOEs. As a percentage of public resources, privatization revenues were particularly important during the initial years of 1991 and 1992, when they represented more than $1 \%$ of GDP and approximately $10 \%$ of public revenues (Heymann and Kosacoff, 2000).

The privatization of the water sector was but a very small portion of the overall privatization program. In fact, the water companies represented only a small fraction of the total SOE production (3.5 percent) and a tiny share of GDP (0.3 percent).

\section{THE PRIVATIZATION OF WATER SERVICES}

From 1870 through 1980, water services in Argentina were provided by the federal company Obras Sanitarias de la Nación (OSN) and a number of not-for-profit cooperatives. In 1980, OSN's jurisdiction was restricted to the federal district and 17 municipalities of the suburban Greater Buenos Aires area. While OSN remained under control of the federal government, the responsibility for public water services in the rest of the country was transferred to local governments (Artana et al, 2000). Most of the companies provided both water and sanitation; however, a few supplied only water. In these cases, there was no sewage service in the community.

In 1990, before privatization, public companies provided water services in two-thirds of the municipalities while not-for-profit cooperatives provided services in the remaining one-third. Between 1991 and 1999, about half of the public water companies servicing 28 percent of the country's municipalities and covering almost 60 percent of the country's population were 
transferred to private for-profit control (see Table 2). The remaining municipalities continued receiving water services from either public companies or nonprofit cooperatives. ${ }^{2}$

In section 2, we argued that the privatization of water services was a small part of a political response to the macro-economic crisis around the turn of the decade. Unlike most sectors that were privatized, the water sector is controlled at the local level, and therefore, the decision to privatize is a local one. In the early 1990s, the newly installed federal government focused its efforts on privatizing the larger centrally controlled SOEs and did not put pressure on local governments to privatize their SOEs until later. Indeed, the privatization of water services accelerated after the elections in 1995, in which the ruling Peronist government was re-elected. This is reflected in Figure 1, which depicts the percentage of municipalities served by private water companies over time. Notice that the rate of privatization of municipalities was slow in the first half of the decade, but accelerated in the second half.

Another hypothesis, which is not incons istent with the political story, is that poorer municipalities with a lower tax base or underdeveloped infrastructure choose to privatize. These are the municipalities that may have had the most to gain from privatization. This hypothesis states that when the whole country started privatizing all SOEs, the municipalities that jumped on the bandwagon were the poorer ones.

However, the hypothesis that poor areas jumped on the privatization bandwagon is different from the hypothesis that the decision to privatize was in response to an economic shock. Whether privatization is driven by time varying shocks is important to the subsequent impact analysis. We propose to exploit the variability in firm ownership across time and space to identify the causal effect of privatization on child mortality using a difference in difference approach in regression form. While this approach controls for time invariant heterogeneity, one of the main threats to its validity is the existence of time-varying unobserved covariates that are correlated

\footnotetext{
2 The only exception is a small mining town in Jujuy, where a private mining company provided water service throughout the period of analysis.
} 
with both privatization and mortality. For example, local economic shocks may affect both the privatization decision and child mortality. While we cannot test this directly, if we find that the decision to privatize is uncorrelated with observed time-varying covariates, then it is less likely to be correlated with unobserved ones.

In order to better understand why some local governments choose to privatize, we estimate a discrete time hazard model of the probability of transiting from public to private water service provision using methods described in Prentice and Gloeckler (1978) and Jenkins (1995). We model the probability that a public water system in a given municipality and period of time is privatized as a function of a set of municipality time-invariant and time-varying covariates, and allow for duration dependence. ${ }^{3}$

First, we include a set of political variables that indicate whether the privatization decision was taken by the central government or by a local government of a particular political affiliation. One would expect that the public water systems controlled by the federal government and local governments controlled by the party in power (Peronist) or provincial parties allied with the Peronists, would be more likely to privatize than municipalities controlled by the opposition Radical party.

One also might expect that poorer regions are more likely to privatize. We measure the socio-economic status of the areas using time-invariant covariates including GDP per capita, income inequality, and unemployment, and a set of characteristics from the 1991 Census such as the proportion of households who have unmet basic needs, housing characteristics, and demographic characteristics of the heads of households.

Another hypothesis is that it is not the level of socio-economic status that matters, but rather socio-economic shocks that cause institutional change. We test this hypothesis by

\footnotetext{
${ }^{3}$ Note that the sample only includes the set of municipalities where water services were operated by public companies in 1990 as nonprofit cooperatives were not at risk of privatization. The exact definitions of the variables and their sources are described in the data appendix, while descriptive statistics are reported in the first column of Table 3 .
} 
including changes in GDP per capita, income inequality, and unemployment lagged one year. We use lagged shocks for two reasons. First, the privatization itself may have affected these timevarying variables, and, second, the long length of time required by privatization processes suggests that the privatization decisions could not have been a response to contemporaneous shocks.

The results are reported in the second column of Table 3. First, as expected, we find that the likelihood of privatization is higher when the federal government or a local government run by the Peronist (or a provincial allied) party administers the public company than when the Radical party controls local government. This is consistent with the fact that the federal government launched the privatization wave of all SOEs, when the Peronists were the party in power and the Radic als were loyal opposition. Second, we used a fifth order polynomial to control for duration dependence, which shows that the likelihood of privatization increased over time. This is consistent with the sequencing of the overall privatization program where the transfer of water systems to private operation occurred later in the decade. Third, the fixed baseline municipality socio-economic characteristics are individually and jointly significantly different from zero, and explain a good portion of the decis ion to privatize. Larger and less well off municipalities appear to be more likely to privatize. Fourth, and more importantly, none of the economic shocks are statistically significant.

While the results discussed above suggest that the decision to privatize is uncorrelated with economic shocks, it might be correlated with mortality for other reasons. Therefore, in the third column of Table 3 we include both the 1991 mortality rate and lagged changes to mortality. In this model we find that both baseline mortality and lagged mortality are not correlated with the privatization decision. 


\section{PATHWAYS}

There are a number of potential pathways by which the privatization of water systems might have affected child mortality. First, privatization may have expanded the water supply and sewage network providing access to service to households that were not previously connected to water and sewage. Second, there may have been improvements in service quality in terms of reduced water and sewage spillage, faster repa ir rates, fewer shortages, cleaner water, and better water pressure and sewage treatment. All of these quality enhancements improve the epidemiological environment (WHO, 2002b). Finally, prices may have changed and the enforcement of service payment cutoffs may have tightened, potentially reducing the access to service by low-income households. In this section, we present evidence that privatization affected these pathways.

\subsection{A Case Study}

The largest privatization was the transfer of the federal company OSN to a private consortium, Aguas Argentinas. The analysis of this privatization, described in Abdala and Spiller (1999), Artana et al (2000), Shirley (2000), and Noll et al (2000), illustrates the changes experienced by water systems in Argentina after the transfer to private operation.

Rather than selling the assets to the private firms, water services were transferred to the private sector through concessions. ${ }^{4}$ In some cases, such as OSN in Buenos Aires, the royalty was set at zero and firms competed for the concession by offering the lowest tariff. In other cases, the privatized companies paid a canon to the government for the use of the public assets. For example, in the provinces of Cordoba and Corrientes, where a canon is paid on an annual basis, the royalty payments represented about $0.4 \%$ and $0.1 \%$ of the fiscal revenues in 1999 , respectively. Thus, the revenue from the water service privatization royalties constituted at best a very small share of the public budget.

\footnotetext{
${ }^{4}$ This is the most common method of privatizing water services worldwide (Noll et al, 2000).
} 
In May 1993 Aguas Argentinas, a consortium lead by the French company Lyonnaise des Eaux, won a 35-year concession to provide water services previously provided by OSN. The terms of the concession stipulated that $100 \%$ of households had to be connected to water service and $95 \%$ to sewage service by the end of the 35 -year period. It also established service quality and waste treatment standards.

Water use fees in Buenos Aires were initially lowered by 26.9 percent as a result of the privatization bid. However, thirteen months after privatization, the regulator authorized a 13.5 percent increase in the usage fee, and a significant increase in connection fees. The increase in the connection fee was controversial as it was very close to the monthly household earnings level for the officialpoverty line. In response to protests, the connection fee was quickly lowered and replaced with a small fixed charge that was added to the water use bills for all clients. This explicit cross-subsidy allowed the firm to reduce the connection fees to about one tenth of the previous levels.

The enforcement of service payment was toughened after privatization. While delinquency was high for OSN, the private operator was allowed to cut service to customers with three unpaid bills (although it could be reconnected under the regulator's request). According to Artana et al (2000) and Water World Vision (2000), over 90 percent of customers regularly pay the service fees, although only about 60 percent do it on time.

Privatization drastically increased efficiency and profitability. Before privatization, OSN was overstaffed as indicated by the fact that employees' average age was above 50 years and absenteeism was high. During the first year under private management, the number of employees was reduced from 7365 to 3800 . The employment reduction, together with the increase in coverage and production, resulted in large productivity increases. In fact, soon after the privatization, the financial performance of Aguas Argentinas became outstanding. After a first year of negative returns, it turned into a highly profitable company (Artana et al, 2000). 
A major question was whether these efficiency gains were translated into service quality improvements. OSN had invested very little in infrastructure during the decade prior to privatization (Galiani et al, 2002). Low revenues and inefficiencies led to such low investment levels that they were not even sufficient to replace depreciating assets and maintain current supply. In 1985 OSN investment was 67.8 percent of what was needed to maintain current supply, and only 19.5 percent in $1990 .^{5}$ In the late 1980 s, water coverage as a share of population was contracting, spilled water rates were very high, pressure and service quality were low, and summer shortages were frequent (Artana et al, 2000).

Things improved dramatically after the privatization. The private company was able to invest a substantial amount in physical infrastructure and service quality. For the ten years before the privatization, OSN invested an average of 25 Million US dollars annually. From 1993 through 2000, Aguas Argentinas's investment jumped to around 200 Million per year. Table 4 shows large increases in water and sewage production, reductions in spillage, and significant service enhancements. In addition, summer water shortages disappeared, repair delays shortened, and water pressure and cleanliness improved.

The investments also paid off in terms of increased access to the network. The number of connections to the water and sewage networks in Buenos Aires expanded by 30 percent and 20 percent, respectively, after privatization. Figure 2 pictures the log of the number of households connected to the OSN-Aguas Argentinas water and sewage network by year from 1986 through 1999. While the number of households connected was relatively flat from 1986 to 1993 , the network grew rapidly each year after privatization.

Moreover, the network expansion was concentrated in the poorer suburban areas of Greater Buenos Aires. Since $98 \%$ percent of households in the city of Buenos Aires were already connected to water services before privatization, most of the expansion in access necessarily had

\footnotetext{
${ }^{5}$ For the whole country, investment in the water sector as a percentage of total domestic investment fell from $1.5 \%$ during the 1960 s to $0.5 \%$ in 1981-1993 (Rey, 2000).
} 
to be among lower income households in the suburban areas. Indeed, Table 5 shows that 84.6 percent of the new connections were to lower-middle and low-income households.

\subsection{Access to Water Services}

While the data for Buenos Aires show that the privatization improved service quality and expanded access to water services, we are unable to similarly assess the impact of privatization for the rest of the country. We are, however, able to say something about the effect of privatization on access to water services. Even though increased access may not be the only mechanism through which privatization can affect child mortality, it is probably one of the most important causal channels. Indeed, acquiring water services for the first time is likely to imply a more important change in access to safe water relative to service improvements to households with existing water and sewage connections.

We evaluate the impact of privatization on access to water services using data from the 1991 Census and the 1997 Encuesta de Desarrollo Social (EDS). The EDS was a stratified random survey of about 30,000 households from urban municipalities with more than 5,000 inhabitants, and asked questions about household connections to water services identical to those asked in the Census.

To identify the effect of privatization on access to water, we exploit the fact that by 1997 a number of municipalities had already privatized their water services (Figure 1). Using the data from municipalities in the EDS survey, we calculate the difference-in-differences estimate of the impact of privatization on the proportion of households who had access to the water network. The difference-in-differences estimator compares the change in the proportion of households connected to water services in municipalities that privatized to the change in the proportion connected in municipalities that did not privatize water services. For this exercise, a municipality is in the privatized group if the privatization of water services occurred between 1990 and 1996 . 
The results, reported in Table 6 , show a significantly larger increase in the proportion of households connected to water services in the municipalities that privatized than in municipalities that did not. The estimated impact is even higher when we exclude the capital city, where 98 percent of households were already connected to water service before privatization. Specifically, the results suggest that the number of households connected to the water network increased by 4.2 percentage points as an outcome of privatization.

This estimate, however, most likely underestimates the impact of privatization on access for two reasons. First, it only includes the impact of privatization through 1997. In Cordoba, for example, water services were privatized in that year and coverage increased by more than 10 percentage points in the first three years of concession. Second, the EDS grossly under-sampled poor areas, and access expanded most in poor areas where fewer households were connected at baseline. ${ }^{6}$ Indeed, Table 5 showed that connections increased the most among the poor in Greater Buenos Aires. And Artana et al (2000) reports that after privatization in Corrientes, one of the poorest provinces in the country, the number of connections to the water network in the province rose by 22 percent and the number of sewerage connections increased by 50 percent.

Finally, results from a recent World Bank household survey (2002b) confirm that network expansions during the privatization period were concentrated in the poorer income groups. The survey inquires about connections to water and sewage services in 1992 (prior to almost all water privatizations) and again in 2002 (well after privatization). Table 7 reports the share of households connected to the water and sewage networks in both years. Overall household connection to the water network increased by 14 percentage points and to the sewage network by 10 percentage points. However, most of the increase came from households in the

\footnotetext{
${ }^{6}$ Specifically, the government measures the poverty of a municipality by the percentage of households with Unmet Basic Needs (UBN) in the 1991 Census. When we split the sample into three groups: non-poor municipalities where less than 25 percent of households have UBN, poor municipalities where between 25 and 50 percent have UBN, and extremely poor municipalities where more than 50 percent have UBN, we found that the EDS does not include any extremely poor municipalities and only includes a few poor municipalities.
} 
lower income groups. Indeed, connections to the water network increased by 21 percentage points and to the sewage network by 16 percentage points among households living in the poorest quintile of the income distribution (see Figure 3). Table 7 demonstrates that while the poor still suffer the lowest connection rates, they have had the largest gains in access after 1993.

\section{THE EFFECT OF PRIVATIZATION ON CHILD MORTALITY}

In this section, we evaluate the impact of the privatization of water services on the mortality of children under five. We focus on young children because they are particularly vulnerable to water-related diseases due to weak body defenses, higher susceptibility, and greater exposure from inadequate knowledge of how to avoid risks; and because water related diseases can easily be prevented through access to clean drinking water, better hygiene and better sanitation (WHO, 2000).

\subsection{Methods}

Our objective is to identify the average effect of privatization on child mortality rates in the municipalities where the water supply system has been privatized (i.e. the average impact of treatment on the treated). Specifically, we are interested in comparing mortality when water services are privately provided compared to the counterfactual-i.e. mortality when services are publicly provided in the treatment areas at the same point in time. Since the counterfactual is never observed, we must estimate it. In principle, we would like to randomly assign private and public ownership across municipalities and compare the average outcomes of the two groups. In the absence of a controlled randomized-trial we are forced to turn to non-experimental methods that mimic it under reasonable conditions.

A major concern is that the municipalities that chose to privatize could be different from the municipalities that chose not to privatize, and that these differences may be correlated with mortality. For example, poorer urban areas where mortality rates were higher may have been the 
ones that privatize. In this case, the correlation between privatization and mortality would be confounded with the wealth effect. In principle, many of the types of (unobservable) characteristics that may confound identification are those that vary across municipalities, but are fixed over time. A common method of controlling for time invariant unobserved heterogeneity is to use panel data and estimate difference in differences models.

Therefore, without the benefit of a controlled randomized trail, we turn to a difference in differences approach, which compares the change in outcomes in the treatment group before and after the intervention to the change in outcomes in the control group. ${ }^{7}$ By comparing changes, we control for observed and unobserved time-invariant municipality characteristics that might be correlated with the privatization decision as well as with mortality. The change in the control group is an estimate of the true counterfactual-i.e. what would have happened to the treatment group if there was no intervention. Another way to state this is that the change in outcomes in treatment areas controls for fixed characteristics and the change in outcomes in the control areas controls for time varying factors that are common to both control and treatment areas.

This difference-in-differences model can be specified as a two-way fixed effect linear regression model:

$$
y_{i t}=a d I_{i t}+\beta x_{i t}+?_{t}+\mu_{i}+e_{i t}
$$

where $\boldsymbol{y}_{i t}$ is the mortality rate in municipality $\boldsymbol{i}$ in year $\boldsymbol{t}, \boldsymbol{d \boldsymbol { I } _ { i t }}$ is an indicator variable that takes on the value one if municipality $\boldsymbol{i}^{\prime}$ s water services are privately provided in year $\boldsymbol{t}$ and 0 otherwise, $\boldsymbol{x}_{i t}$ is a vector of control variables that vary both across municipalities and time, $\mu_{i}$ is a fixed-effect unique to municipality $\boldsymbol{i}, \lambda_{t}$ is a time effect common to all municipalities in period $t$, and $\varepsilon_{i t}$ is a municipality time-varying error distributed independently across municipalities and time and independently of all $\mu_{i}$ and $\lambda_{t}$ (see Chamberlain, 1984; and Heckman and Robb, 1985). In this

\footnotetext{
${ }^{7}$ The difference in difference estimator is one of the most widely used in the evaluation literature (see, among others, Angrist, 1995; and Heckman et al, 2000).
} 
model, $\alpha$ is the difference in difference estimate of the (average) effect of privatization of water services on mortality.

There are three critical assumptions for $\alpha$ to be an unbiased estimate of the program impact. The first is the assumption that the change in mortality in control areas is an unbiased estimate of the counterfactual-i.e. what would have happened to mortality in the treatment areas if water services had not been privatized. While we cannot directly test this assumption, we can test whether the secular time trends in the control and treatment municipalities were the same in the pre-intervention periods (Heckman and Hotz, 1989). If the secular trends are the same in the pre-intervention periods, then it is likely that they would have been the same in the post intervention period if the treated municipalities had not privatized.

The second concern is that there may be unobserved characteristics that vary across time and space, and that are correlated with both mortality and privatization. For example, it could be that the areas that privatized were also hit by positive economic shocks or there were improvements in the health care system or increases in public welfare programs at the time they privatized.

We address this concern in three ways. First, the analysis in section 3 provided evidence consistent with the notion that privatization is driven by fixed characteristics and not by the observed time-varying variables. This suggests that privatization is also less likely to be correlated with time-varying location-specific unobserved shocks. Second, we directly control for a number of observed time-varying economic and political characteristics such as GDP per capita, unemployment, income inequality and bcal public spending. Finally, we investigate the impact of privatization on mortality by cause of death. The privatization of water should affect only mortality caused by infectious and parasitic diseases and not affect mortality from other causes. 
The third concern is that the impact of treatment on the treated may not be homogenous across municipalities, but rather vary as a function of the characteristics of the municipalities. For example, the impact of the privatization may matter more in areas where families are better educated. In this case, simple difference in difference estimates may suffer from two additional sources of bias (Heckman et al, 1997, and Heckman et al, 1998a). The first bias arises when there are some municipalities where privatization has taken place, but there are no comparable municipalities for which privatization did not occur and vice versa. The second bias may arise from different distributions of the vector of observable variables that affect mortality $(\mathbf{x})$ within the two groups of municipalities. ${ }^{8,9}$

Matching methods eliminate these two potential sources of bias by pairing privatized municipalities (treatments) with non-privatized municipalities (controls) that have similar observed attributes. Using observations in the treatment and control groups over the region of common support in the distribution of $\mathbf{x}$ eliminates the first source of concern, while the bias due to different distributions of $\mathbf{x}$ between treated and untreated municipalities within this common support is eliminated by reweighting the control group observations.

In general, conventional matching methods assume that, conditional on the observed variables $\mathbf{x}$, the counterfactual outcome distribution of the treated units is the same as the observed outcome distribution of the units in the control group. This assumes that there is no selection into treatment on the basis of unobservables. To avoid the necessity of this assumption, Heckman et al (1998b) propose a generalized difference in differences matching estimator that extends conventional matching methods to longitudinal data. By conditioning on fixed-effects, the generalized difference-in-differences estimator identifies the parameter of interest without ruling out selection into treatment on the basis of time-invariant unobservables.

\footnotetext{
${ }^{8}$ The vector $\mathbf{x}$ includes variables that vary only across municipalities and also across time and municipalities.

${ }^{9}$ Heckman et al (1997) suggests that, in practice, the first of these two sources of bias is likely to be the most severe.
} 
The objective, then, is to construct a control group by finding controls that have similar observed x's as the treatments. Rosenbaum and Rubin (1983) show that to match treated and untreated units on the basis of $\mathbf{x}$ is equivalent to match them using a balancing score $\mathrm{B}(\mathbf{x})$. The coarsest balancing score is the propensity score which gives the conditional probability of receiving treatment given the pre-treatment values of the vector $\mathbf{x}$, i.e. $\operatorname{P(x)}=\operatorname{Pr}(D=1 \mid \mathbf{x})$. Then, the method of matching assumes that conditional on $P(\mathbf{x})$, the counterfactual outcome distribution of the treated units is the same as the observed outcome distribution of the controls. This result is very important in practice since it reduces the potential problem of matching on a high dimensional vector $\mathbf{x}$ to matching on a scalar.

We estimate propensity scores from a logit model of the probability that a municipal water system that was public in 1990 was privatized sometime before the year 2000 as a function of the pre-intervention characteristics used in Column 2 of Table 3. These models are then used to predict the propensity (probability) that a municipality will privatize.

We identify control and treatment observations on a common support as follows. We exclude all control observations whose propensity scores are less than the propensity score of the treatment municipality at the first percentile of the treatment propensity score distribution, and exclude all treatment observations whose propensity score is greater than the propensity score of the control observation at the $99^{\text {th }}$ percentile of the control distribution. Then, our second set of estimates is obtained as difference-in-differences on the observations that lie on this common support. Finally, we use a kernel density weighting procedure to obtain the generalized difference-in-differences matching estimator (see Heckman et al, 1997). ${ }^{10}$

\footnotetext{
10 The bootstrapped standard errors of the matching estimates also address the potential serial correlation concern in differences-in-differences models (Bertrand et al, 2001).
} 


\subsection{Measuring Mortality}

The dependent variable in our analysis is the child mortality rate constructed from information contaned in vital statistics registries compiled by the Argentine Ministry of Health. The database includes the 165,542 child deaths that occurred from 1990 through $1999,{ }^{11}$ and is aggregated to the municipality level on an annual basis for 20 pathology groups

Mortality rates are traditionally defined as the probability a child dies before she reaches age five, and is usually approximated by the number of deaths of children less than five years old divided by the number of kids born that year. Applying this definition of child mortality to vital statistics, the mortality rate in Argentina has fallen from 72 per 1,000 live births in 1960 to 22 in 1999.

Rather than using the probability that a child dies before she reaches age five, we prefer to use the probability that a child less than five years old dies in a given year. Therefore, we measure our dependent variable as the ratio of number of deaths of children less than five years old to the total number of children less than five alive at the beginning of the year. We estimate the total number of children using census data and the vital statistics records. Our results do not change when we use the more traditional definition. In that case, the estimated coefficients are equal to five times ours.

\subsection{Control Groups}

Our main result is evident in Figure 4, which depicts the evolution of the mortality rates per 1,000 for privatized and non-privatized water companies. Until 1995, the mortality rates of the municipalities that privatized their water systems decreased at the same rate as the mortality rates of the municipalities that did not privatize. However, after 1995 the mortality rates of the municipalities that privatized decreased faster than the mortality rates of those that did not

\footnotetext{
${ }^{11}$ We exclude from the analysis 5,042 child deaths for which the municipality is unspecified. The mortality data is not available at the municipality level before 1990.
} 
privatize. This timing is commensurate with the timing of privatization (Figure 1). Before 1995 only a few municipalities had privatized; whereas the bulk of privatizations occurred after 1995.

The fact that the levels and trends in mortality rates in both groups of municipalities were the same before privatization is important. One of the threats to the validity of the difference-indifference approach is that the post intervention trend in the control group could be a poor estimate of the counterfactua—i.e. what would have happened to the treatment group if there had not been an intervention. Since the control and treatment group time trends are the same in the pre-intervention period, it is hard to believe that they would be different in the post-intervention period had there been no intervention. Moreover, not only do both groups have the same trends in the pre-intervention period, they also have the same levels.

We formally test that the pre-intervention time trends for the control and treatment groups are not different by estimating a slightly modified version of equation (1). We use only the observations of the control municipalities and the treatment municipalities in the pretreatment period-i.e. we use 1990-98 for all of the control municipalities and only the pre-intervention years for the treatments municipalities. This covers nine of the ten years since a number of treatment municipalities were not privatized until 1999, the last year of our sample. We modify equation (1) by excluding the privatization dummy variable and including separate year dummies for (eventual) treatments and controls. In this model, we cannot statistically reject the hypothesis that the pre-intervention year dummies are the same for both the control and (eventual) treatment municipalities at any conventional level of significance. This implies that the mortality rates in treatment and control groups had identical time trends in the "pre-treatment" period and validates our difference-in-differences identification strategy (Heckman and Hotz, 1989).

A related issue is that we are using both the municipalities that always had public provision of water services and the municipalities that had nonprofit cooperatives as controls. While the cooperatives were never susceptible of privatization, they are just as good as the always-public municipalities as controls for estimating the counterfactual. In fact, when we 
estimate separate year dummies for the always-public and cooperative municipalities in a mortality model for the whole sample period, we do not reject the hypothesis that these year dummies are the same at any conventional level of significance. This implies that the mortality trends of the always public and cooperative municipalities were the same over the sample period, and therefore they are equally as good in predicting the counterfactual. However, while the cooperatives serve as valid controls for secular trends, our results can only be interpreted as the impact of privatization of public companies on mortality and says nothing about the possible privatization of cooperatives, as we observe no cooperatives converting to for-profit private companies in the sample.

\subsection{Main Results}

We present the estimation results for child mortality from all causes of death in Table 8. Each column reports the results from a different specification using the same dependent variable. The first three columns report the results for the whole sample, while the last four columns report the results using municipalities only with observable characteristics on the common support of the distribution of propensity scores.

The first column reports the results for a model using the whole sample and includes no covariates except for municipality fixed effects and year dummies. We find that the privatization of water services is associated with a 0.33 reduction in the mortality rate, which amounts to a 5.3 percent reduction of the baseline rate. Both the year and municipality fixed effects are jointly significantly different from zero. However, a Hausman test cannot reject the hypothesis that the fixed effect and random effect estimates are the same. This suggests that the treatment variable is uncorrelated with the fixed municipality unobservables.

One concern with these results is that there may have been positive economic shocks to municipalities that privatized, which caused the reduction in mortality. In order to test this hypothesis, we included GDP per capita, unemployment, income inequality, and public spending 
per capita in a model reported in column 2. The public spending variable controls for the possibility that the impact of privatization is coming from correlated improvements in the local public programs. However, only inequality appears to be significantly correlated with child mortality at the ten percent le vel. More importantly, the estimated impact of privatization is unchanged.

A related concern is that the same political parties that choose to privatize might, in general, run better administrations or have stronger preferences for child mortality reduction in ways not properly captured by the public spending variable. In model 3 , we add dummy variables for the political party that controlled the local government. While it appears that mortality rates were marginally higher when the Radical party took over, the estimated impact of privatization was unaffected. Overall, we find that privatization is associated with a significant reduction in the child mortality rate of about 5 percent using the full sample regardless of the choice of controls.

However, the estimated impact of privatization on mortality increases when we restrict the sample to observations only on the common support of the propensity score. In columns 4 through 6 we report the results of estimating models 1 through 3 restricting the sample to observations on the common support. In the basic model of column 4, privatization is associated with an 8.6 percent fall in the child mortality rate. This estimate does not change when we control for socio-economic characteristics in column 5 and for political variables in column 6 . While there is no longer a statistical difference in mortality by political party, increases in public spending now appear to be significantly associated with lower mortality.

Finally, the generalized difference in difference estimate, which uses kernel density weighted matches on the common support, is reported in the last column. The model estimates that privatization is associated with a 10 percent reduction in the child mortality rate.

In summary, the results, regardless of method, show a statistically significant negative association between privatization and child mortality. The estimated impact varies from 4.5 
percent to 10.0 percent of the baseline mortality rate. While the addition of time-varying controls does not change the estimated impact, conditioning on control and treatment observations that have common support increases the estimated impact by over 60 percent. However, adding kernel density weighted matching only increases the estimated impact by less than 20 percent. This is consistent with the results in Heckman et al (1998a) where they evaluated matching estimates using data from a controlled randomized experiment and found that the main source of bias comes from not restricting the estimates to the observations on the common support.

\subsection{Results by Cause of Death}

In spite of the robustness of our results to the inclusion of the economic and political controls, it is still possible that at the time of privatization there may have been some other unobserved changes in the municipalities that privatized that are correlated with mortality in general. For example, there may have been enhancements in the health care system or increases in public welfare programs not captured by the public spending or political variables. It is also possible that that there were different migratory trends among treated and untreated municipalities.

In order to rule out possible unobserved changes correlated with privatization, we examine the impact of privatization on mortality by cause of death. The mortality data is disaggregated for 20 specific pathology groups. The privatization of water provision on child mortality should mainly operate by affecting deaths from infectious and parasitic diseases. These deaths are classified into two of the pathology groups. If the death occurred after the first 28 days of life, it is classified in the Infectious and Parasitic Diseases group. However, all deaths that occurred during the first 28 days of life are placed into the Perinatal Deaths category, regardless of the cause. Thus, even if the death occurred from an infectious or parasitic disease it is assigned to the Perinatal Deaths during the first 28 days of life, and not to the Infectious and Parasitic Diseases category. Therefore, if the observed reduction in child mortality is operating through 
improved access and quality of water, then we should see significant negative effects on deaths in the Perinatal Deaths and Infectious and Parasitic Diseases categories, and negligible effects on deaths from other causes such as accidents, cardiovascular diseases, or cancer.

We estimate the difference in difference models using municipalities with common support and all socio-economic and political controls for mortality rates for each cause of death. ${ }^{12}$ The results are reported in Table 9. As predicted, we find a statistically significant effect on mortality from infectious and parasitic diseases (and perinatal deaths), but no statistically significant effect on mortality from any other cause either separately or in aggregate. In fact, the estimated impact is higher for infectious and parasitic diseases (18.2 percent) than for perinatal deaths (11.5 percent). This is consistent with the fact that safe water potentially affects more of the deaths in infectious and parasitic diseases category than it does for the perinatal category, in which other non-water related diseases are also included.

The importance of this result cannot be overemphasized. Privatization could only be spuriously capturing the effect of unobservables if those uncontrolled variables are correlated with deaths from infectious and parasitic diseases, but not with deaths from any other cause. This result rules out the presence of almost any other plausible explanation of our main results and leads us to believe in their causal interpretation.

\subsection{Impact by Socioeconomic Status}

We hypothesize that privatization should have had a higher impact on child mortality in poor municipalities than in wealthier ones. Middle and high-income groups already had a high rate of connection to the water network prior to privatization. Even when they were not connected or when service quality was unsatisfactory, these income groups enjoyed better access to

\footnotetext{
${ }^{12}$ As we are analyzing child mortality, we exclude from this exercise the analysis of deaths from suicides; homicides; other violent deaths; and pregnancy, labor, delivery and puerperal diseases. We also exclude the residual category of undefined causes.
} 
substitutes such as pumped wells, septic tanks, or bottled water than poor households. The main beneficiaries of network expansions and service enhancements, therefore, were low-income households who also are the groups most vulnerable to child mortality.

In Table 10 we report the estimated impact of water privatization on child mortality at three different ranges of poverty at the municipality level. To estimate these heterogeneous impacts of privatization on child mortality, we interact the treatment dummy variable with a poverty indicator function from the 1991 Census. We construct three ranges of poverty: municipalities with a percent of households suffering from Unmet Basic Needs (UBN) lower to 25\%, municipalities with UBN between 25 and 50\%, and municipalities with UBN higher than $50 \%$.

We find that the privatization of water systems does not affect mortality in those municipalities with low levels of poverty (UBN lower than 25\%). The effect on the remaining treated municipalities is increasing in the level of poverty and highly significant. In fact, the privatization of water systems is associated with a 26.5 percent reduction in child mortality in municipalities with high levels of poverty (UBN greater than 50\%). This result is consistent with the predictions of our causal model. The effect of privatization on child mortality should be stronger for the groups that are more vulnerable to water related diseases.

\section{CONCLUSIONS}

During the 1990s Argentina launched a massive privatization program as part of a large plan of structural reforms. The program included the privatization of local water companies providing service to approximately 30 percent of the municipalities and 60 percent of the population. Available information from a number of case studies demonstrates that the newly privatized water firms were more efficient, invested more in physical infrastructure, and provided better service quality than their previous public incarnations. Indeed, our evidence on access to service shows that the network connections increased significantly in the areas that privatized. 
We hypothesized that increased access to the water and sanitation network, and potential changes in service quality, improved health outcomes of young children. Using a combination of methods, we find that child mortality fell by approximately 8 percent in the areas where water systems were privatized. A number of factors lead us to believe that the link between the privatization of water systems and the decrease in child mortality is causal. First, privatization decisions across municipalities and time do not depend on time-varying variables that may also affect mortality rates. Second, the treatment and control groups showed similar trends in the preintervention period. Third, water privatization affected child mortality from water-related diseases but it showed no effect on deaths from other causes. Fourth, the impact of privatization was largest in poorest areas.

Our results shed light on a number of important policy debates. First, while the previous literature demonstrates that privatization raises firms' productivity and profitability, it does not address the question of whether privatization actually increases social welfare. We show that privatization reduces child mortality, a direct and tangible welfare indicator.

Second, many fear that private operators would fail to take into account the significant health externalities that are present in this industry, and therefore under-invest and supply suboptimal service quality. On the contrary, our evidence suggests that the deterioration in performance of water systems in Argentina under public management was so large that it allowed for a privatization that generated private profits, improved access, expanded service, and reduced child mortality. While the regulated private sector may not be providing first best services, they seem to be doing a much better job than the public sector.

Finally, there is a growing public perception that privatization hurts the poor. This perception is driven by the belief that privatized companies raise prices, enforce service payment, and invest only in lucrative high-income areas. In contrast, we find that the poorest population experienced the largest gains from privatization in terms of reduction in child mortality.

Privatization appears to have had a progressive effect on reducing health inequality. 


\section{DATA APPENDIX: DEFINITIONS AND SOURCES}

\begin{tabular}{|c|c|c|}
\hline Variable & Definition & Source \\
\hline Child Deaths & $\begin{array}{l}\text { Number of deaths of children less than } 5 \text { years old by } \\
\text { municipality by year by cause of death. }\end{array}$ & $\begin{array}{l}\text { Ministerio de Salud de la República } \\
\text { Argentina, 1990-99. }\end{array}$ \\
\hline Child Population & $\begin{array}{l}\text { Number of children less than } 5 \text { years old by municipality by } \\
\text { year. Obtained by linear extrapolation from the } 1991 \\
\text { Census using the 1990-2000 INDEC estimates of total } \\
\text { municipality population. }\end{array}$ & $\begin{array}{l}\text { INDEC, Censo Nacional de } \\
\text { Población y Vivienda 1991. INDEC, } \\
\text { Proyecciones de Población por } \\
\text { Localidad 1990-2000. }\end{array}$ \\
\hline $\begin{array}{l}\text { Child Mortality } \\
\text { Rate }\end{array}$ & $=$ Child Deaths / Child Population. & \\
\hline $\begin{array}{l}\text { Private Water } \\
\text { Services }\end{array}$ & $\begin{array}{l}\text { Dummy variable }=1 \text { if the largest fraction of the population } \\
\text { in the municipality is supplied by a private water company, } \\
\text { and } 0 \text { otherwise. }\end{array}$ & $\begin{array}{l}\text { Sistema Permanente de } \\
\text { Información de Saneamiento, Ente } \\
\text { Nacional de Obras Hídricas de } \\
\text { Saneamiento, www.enohsa.gov.ar. }\end{array}$ \\
\hline $\begin{array}{l}\text { Unemployment } \\
\text { Rate }\end{array}$ & $\begin{array}{l}\text { Unemployment rate (May and October average) for } \\
\text { households in the surveyed cities of the province in which } \\
\text { the municipality is located. }\end{array}$ & $\begin{array}{l}\text { Permanent Household Survey } \\
\text { (EPH), INDEC 1990-1999. }\end{array}$ \\
\hline Income Inequality & $\begin{array}{l}\text { Gini Index (May and October average) for households in } \\
\text { the surveyed cities of the province in which the municipality } \\
\text { is located. }\end{array}$ & See Unemployment Rate. \\
\hline GDP Per Capita & $\begin{array}{l}\text { Per capita gross geographic product in hundreds of } \\
\text { constant pesos in the province in which the municipality is } \\
\text { located. }\end{array}$ & $\begin{array}{l}\text { Consejo Federal de Inversiones and } \\
\text { INDEC. }\end{array}$ \\
\hline Population & Total population in the municipality in 1991. & $\begin{array}{l}\text { INDEC, Censo Nacional de } \\
\text { Población y Vivienda } 1991 .\end{array}$ \\
\hline $\begin{array}{l}\text { Overcrowded } \\
\text { Housing }\end{array}$ & $\begin{array}{l}\text { Fraction of municipality's households with an average of } \\
\text { more than three people per room in } 1991 .\end{array}$ & See Population. \\
\hline No Toilet & $\begin{array}{l}\text { Fraction of municipality's households with no fecal } \\
\text { evacuation system in } 1991 .\end{array}$ & See Population. \\
\hline Poor Housing & $\begin{array}{l}\text { Fraction of municipality's households living in poor housing } \\
\text { in } 1991 .\end{array}$ & See Population. \\
\hline $\begin{array}{l}\text { Below } \\
\text { Subsistence }\end{array}$ & $\begin{array}{l}\text { Fraction of municipality's households with } 4 \text { or more } \\
\text { members per working member and low household-head } \\
\text { education in } 1991 .\end{array}$ & See Population. \\
\hline $\begin{array}{l}\text { Unmet Basic } \\
\text { Needs }\end{array}$ & $\begin{array}{l}\text { Fraction of municipality's households with Unmet Basic } \\
\text { Needs (i.e. at least one of the following: Overcrowded } \\
\text { Housing, No Toilet, Poor Housing, or Below Subsistence) } \\
\text { in } 1991 .\end{array}$ & See Population. \\
\hline $\begin{array}{l}\text { Household Head } \\
\text { Age }\end{array}$ & Mean age of household heads in the municipality in 1991. & See Population. \\
\hline No Sewage & $\begin{array}{l}\text { Dummy variable }=1 \text { if sewage was not provided in } \\
\text { municipality in } 1991 \text {, and } 0 \text { otherwise. }\end{array}$ & See Population. \\
\hline $\begin{array}{l}\text { Unemployment } \\
1991\end{array}$ & Municipality unemployment rate in 1991. & See Population. \\
\hline $\begin{array}{l}\text { Head Education } \\
\text { above High } \\
\text { School }\end{array}$ & $\begin{array}{l}\text { Fraction of households where head has educational level } \\
\text { above high school in } 1991 .\end{array}$ & See Population. \\
\hline $\begin{array}{l}\text { Federal } \\
\text { Government } \\
\text { Operates Services }\end{array}$ & $\begin{array}{l}\text { Dummy variable }=1 \text { if the company providing water } \\
\text { services depends on the federal government, and } 0 \\
\text { otherwise. }\end{array}$ & See Private Water Services. \\
\hline $\begin{array}{l}\text { Local Government } \\
\text { by Radical Party }\end{array}$ & $\begin{array}{l}\text { Dummy variable }=1 \text { if the Union Civica Radical party } \\
\text { governs province in which the municipality is located, and } 0 \\
\text { otherwise. }\end{array}$ & Jones et al (2000). \\
\hline $\begin{array}{l}\text { Local Government } \\
\text { by Peronist Party }\end{array}$ & $\begin{array}{l}\text { Dummy variable }=1 \text { if the Peronist party governs province } \\
\text { in which the municipality is located, and } 0 \text { otherwise. }\end{array}$ & $\begin{array}{l}\text { See Local Government by Radical } \\
\text { Party. }\end{array}$ \\
\hline $\begin{array}{l}\text { Public Spending } \\
\text { Per Capita }\end{array}$ & $\begin{array}{l}\text { Public spending per capita in hundreds of constant pesos } \\
\text { in the province in which the municipality is located. }\end{array}$ & DataFiel and INDEC. \\
\hline
\end{tabular}




\section{References}

Abdala, M. and P. Spiller (1999): “Agua y Saneamiento”, in Instituciones, Contratos y Regulación en Argentina, Buenos Aires: TEMAS.

Angrist, J. (1995): "Introduction to the JBES Symposium on Program and Policy Evaluation", Journal of Business and Economic Statistics 13, pp. 249-88.

Armstrong, M., S. Cowan, and J. Vickers (1994): Regulatory Reform: Economic Analysis and British Experience, Cambridge: MIT Press.

Artana, D., F. Navajas and S. Urbiztondo (2000): "Governance and Regulation in Argentina", in Savedoff, W. and P. Spiller (eds.), Spilled Water, Washington D.C.: IDB Press.

Barberis N., M. Boycko, A. Shleifer and N. Tsukanova (1996): "How Does Privatization Work? Evidence from the Russian Shops", Journal of Political Economy 104 (4), pp. 764-90.

Behrman, J. and B. Wolfe (1987): “How Does Mother's Schooling Affect Family Health, Nutrition, Medical Care Usage and Household Sanitation?", Journal of Econometrics 36, pp. 185-204.

Bertrand, M., E. Duflo and S. Mullainathan (2001) "How Much Should We Trust Differences-inDifferences Estimates?", mimeo.

Birdsall, N. and J. Nellis (2002): "Winners and Losers: Assessing the Distributional Impact of Privatization", Working Paper Number 6, Center for Global Development.

Cebu Team (1991): "Underlying and Proximate Determinants of Child Health: The Cebu Longitudinal Health and Nutrition Survey", American Journal of Epidemiology 33 (2), pp. 185-201.

CEP (1998): "Privatizaciones: Un Balance Cuantitativo", Buenos Aires, Ministerio de Economía, www.minproduccion.gov.ar/cep_anteriores/notas/notas8/nota3.htm.

Chamberlain, G. (1984): "Panel Data", in Griliches, Z. and M. Intriligator (eds.), $\underline{\text { Handbook of }}$ Econometrics, Volume 2, Amsterdam: North-Holland.

Chisari, O., A. Estache, and C. Romero (1999): "Winners and Losers from the Privatization and Regulation of Utilities: Lessons from a General Equilibrium Model of Argentina", World Bank Economic Review, 13 (2), pp. 357-78.

Esrey, S., J. Potash, L. Roberts, and C. Shiff (1991): "Effects of Improved Water Supply and Sanitation on Ascariasis, Diarrhea, Dracunculiasis, Hookworm Infection, Schistosomiasis and Trachoma", Bulletin of the World Health Organization, 69 (5), 609-21.

Estache, A. , A. Gomez-Lobo, and D. Leipziger (2001): "Utilities Privatization and the Poor: Lessons and Evidence from Latin America”, World Development, 29 (7), pp. 1179-98.

Foster, V. (1999): "Literature Review for Regional Studies Project on Privatization and Infraestructure Services of the Urban Poor", mimeo, World Bank.

Finnegan, W. (2002): "Letter from Bolivia: Leasing the Rain”, The New Yorker, April 8, pp. 4353.

Frydman, R., C. Gray, M. Hessel, and A. Rapaczynsku (1999): "When Does Privatization Work? The Impact of Private Ownership on Corporate Performance in the Transition Economies", Quarterly Journal of Economics 114 (4), pp. 1153-91. 
Galiani, S. and D. Petrecolla (1996): “The Changing Role of the Public Sector: An Ex-post View of the Privatization Process in Argentina", Quarterly Review of Economics and Finance 36 (2), pp. 131-52.

Galiani, S., P. Gertler, E. Schargrodsky and F. Sturzenegger (2002): "The Benefits and Costs of Privatization in Argentina: A Microeconomic Analysis", forthcoming in Chong, A. and F. Lopez-de-Silanes (eds.), The Benefits and Costs of Privatizations.

Gerchunoff, P., editor (1992): Las Privatizaciones en Argentina - Primera Etapa, Buenos Aires: Instituto Torcuato Di Tella.

Heckman, J. and V. Hotz (1989): "Choosing among Alternative Non-experimental Methods for Estimating the Impact of Social Programs: The Case of Manpower Trainin g", Journal of the American Statistical Association 84 (408), pp. 862-74.

Heckman, J., H. Ichimura and P. Todd (1997): "Matching as an Econometric Evaluation Estimator: Evidence from Evaluating a Job Training Program", Review of Economic Studies 64 (4), pp. 605-54.

Heckman, J., H. Ichimura, J. Smith and P. Todd (1998a): "Characterizing Selection Bias using Experimental Data", Econometrica 66 (5), pp. 1017-98.

Heckman, J., H. Ichimura and P. Todd (1998b): "Matching as an Econometric Evaluation Estimator", Review of Economic Studies 65 (2), pp. 261-94.

Heckman, J., R. LaLonde and J. Smith (2000): “The Economics and Econometrics of Active Labor Market Programs", in Ashenfelter, O. and D. Card (eds.), Handbook of Labor Economics, Volume 3A, Amsterdam: North-Holland.

Heckman, J. and R. Robb Jr. (1985): "Alternative Methods for Evaluating the Impact of Interventions: An Overview”, Journal of Econometrics 30 (1-2), pp. 239-67.

Heymann, D. and B. Kosacoff (2000): La Argentina de los Noventa. Desempeño Económico en un Entorno de Reformas, Buenos Aires: EUDEBA.

Heymann, D. and F. Navajas (1989): "Conflicto Distributivo y Déficit Fiscal. Notas sobre la Experiencia Argentina, 1970-1987”, Desarrollo Económico 29 (115), pp. 309-29.

IDB (2002): “The Privatization Paradox”, Latin American Economic Policies 18.

Jalan, J. and M. Ravallion (2002): "Does Piped Water Reduce Diarrhea for Children in Rural India?", forthcoming in Journal of Econometrics.

Jenkins, S. (1995): "Easy Estimation Methods for Discrete-time Duration Models", Oxford Bulletin of Economics and Statistics 57 (1), pp. 129-138.

Jones, M., P. Sanguinetti and M. Tommasi (2000): "Voters as Fiscal Liberals", mimeo, Centro de Estudios para el Desarrollo Institucional (CEDI).

La Porta, R. and F. Lopez-De-Silanes (1999): “The Benefits of Privatization: Evidence from Mexico", Quarterly Journal of Economics 114 (4), pp. 1193-1242.

Lavy, V., J. Strauss, D. Thomas, and P. de Vreyer (1996): "Quality of Health Care, Survival and Health Outcomes in Ghana", Journal of Health Economics 15, pp. 333-57.

Lee, L., M. Rosenzweig, and M. Pitt (1997): "The Effects of Improved Nutrition, Sanitation, and Water Quality on Child Health in High-Mortality Populations", Journal of Econometrics 77, pp. 209-35. 
McKenzie, D. and D. Mookherjee (2002): "Distributive Impact of Privatization in Latin America: An Overview of Evidence from Four Countries", forthcoming in Economia.

Megginson, W., R. Nash, and M. van Randenborgh (1994): “The Financial and Operating Performance of Newly Privatized Firms: An Interpretational Empirical Analysis", Journal of Finance 49 (2), pp. 403-52.

Merrick, T. (1985): “The Effect of Piped Water on Early Childhood Mortality in Urban Brazil, 1970 to 1976", Demography 22 (1), pp. 1-24.

Ministerio de Economía (2000): "El Proceso de Privatizaciones en la Argentina desde una Perspectiva del Balance de Pagos", Buenos Aires: Ministerio de Economía.

Ministerio de Salud (1999): "Programa Nacional de Estadísticas de Salud, Defunciones de Menores de 5 Años, Argentina 1997”, Buenos Aires: Ministerio de Salud.

Noll, R., M. Shirley and S. Cowan (2000): "Reforming Urban Waster Systems in Developing Countries" in A. Krueger (ed.) Economic Policy Reform: The Second Stage, Chicago: University of Chicago Press.

Prentice, R. and L. Gloeckler (1978): "Regression Analysis of Grouped Survival Data with Application to Breast Cancer Data", Biometrics 34, pp. 57-67.

Rey, O. (2000): El Saneamiento en el Area Metropolitana: Desde el Virreinato a 1993, Buenos Aires: Aguas Argentinas.

Rosenbaum, P. and D. Rubin (1983): "The Central Role of the Propensity Score in Observational Studies for Causal Effects", Biometrika 70, pp. 41-55.

Shirley, M. (2000): "Reforming Urban Water Systems: A Tale of Four Cities" in L. Manzetti (ed.) Regulatory Policy in Latin America: Post Privatization Realities, Coral Gables: North-South Center Press, University of Miami.

Shleifer, A. and R. Vishny (1994): "Politicians and Firms", Quarterly Journal of Economics 109 (4), pp. 995-1025.

Shleifer, A. (1998): “State versus Private Ownership", Journal of Economics Perspectives 12 (4), pp. 133-50.

Tagliabue, J. (2002): “As Multinationals Run the Taps, Anger Rises over Water for Profit”, The New York Times, August 26.

UNICEF (2001): Estado Mundial de la Infancia, New York: UNICEF.

Water World Vision (2000): “Informe Nacional sobre la Gestión del Agua en Argentina”, mimeo.

WHO (2000): Global Water Supply and Sanitation Assessment 2000 Report, Geneva: World Health Organization.

WHO (2002a): Children's Health and Environment: A Review of Evidence, Copenhagen: European Environment Agency and World Health Organization, Regional Office for Europe.

WHO (2002b): Water and Health, Copenhagen: European Environment Agency and World Health Organization, Regional Office for Europe.

World Bank (2002a): "Water - The Essence of Life", Development News, May 17.

World Bank (2002b): "Estudio sobre el Diseño de una Política Social para los Servicios de Infraestructura en Argentina", mimeo. 
Table 1: Privatization of Federal Argentine SOEs

\begin{tabular}{|c|c|c|}
\hline Sector Privatized & $\begin{array}{l}\text { Total Sale Income } \\
\text { (Millions of US\$) }\end{array}$ & Dates Privatized \\
\hline Oil and Gas Production & 7,594 & 1990 to 1999 \\
\hline Electricity & 3,908 & 1992 to 1998 \\
\hline Communications & 2,982 & 1990 to 1992 \\
\hline Gas Transport and Distribution & 2,950 & 1992 to 1998 \\
\hline Transportation & 756 & 1990 to 1994 \\
\hline Petrochemical and Oil Derivatives & 554 & 1991 to 1995 \\
\hline Banks and Finance & 394 & 1994 to 1999 \\
\hline Steel & 158 & 1992 to 1992 \\
\hline Other & 126 & 1991 to 1999 \\
\hline Railways & Concession & 1991 to 1995 \\
\hline Highways & Concession & 1990 to 1993 \\
\hline Ports & Concession & 1990 to 1994 \\
\hline Airports & Concession & 1998 \\
\hline Radio and TV & Concession & 1990 to 1991 \\
\hline Water and Sewage & Concession & 1993 \\
\hline Mail Service & Concession & 1997 \\
\hline Total Privatization Revenue ${ }^{(a)}$ & 19,422 & \\
\hline
\end{tabular}

Notes: (a) The total revenue from privatization does not include royalty payments from companies privatized through concessions or revenues from the privatization of provincial and municipal SOEs. Source: Ministerio de Economía (2000).

Table 2: Change in Ownership of Water Systems 1990-1999

\begin{tabular}{lcc}
\hline Ownership $^{(a)}$ & Number of Municipalities & Percentage \\
\hline Always Public & 196 & $39.7 \%$ \\
Always Private Not-for-profit Cooperative & 143 & $28.9 \%$ \\
Transferred From Public to Private For-Profit & 138 & $27.9 \%$ \\
Always Private For-Profit & 1 & $0.2 \%$ \\
No Service or Missing Information & 16 & $3.2 \%$ \\
Total & 494 & $100.0 \%$ \\
\hline
\end{tabular}

Notes: (a) In municipalities where more than one company provides water services, we defined the ownership status of the municipality as the ownership of the company supplying the largest fraction of the population. Source: SPIDES, ENOHSA. 
Table 3: Discrete Time Hazard Estimate of the Probability of Being Privatized

\begin{tabular}{|c|c|c|c|}
\hline & $\begin{array}{c}\text { Means } \\
\text { (Std. Dev.) }\end{array}$ & Model $1^{\text {(a) }}$ & Model $2^{(a)}$ \\
\hline \multicolumn{4}{|l|}{ Time-varying covariates: } \\
\hline Federal Government Operates Services $(=1)$ & $\begin{array}{c}0.018 \\
(0.134)\end{array}$ & $\begin{array}{c}15.975^{* * *} \\
(2.719)\end{array}$ & $\begin{array}{c}16.035^{* * *} \\
(2.727)\end{array}$ \\
\hline Local Government by Radical Party $(=1)$ & $\begin{array}{c}0.139 \\
(0.346)\end{array}$ & $\begin{array}{c}-3.198^{* * *} \\
(1.067)\end{array}$ & $\begin{array}{c}-3.204^{\star * *} \\
(1.067)\end{array}$ \\
\hline Local Government by Peronist Party $(=1)$ & $\begin{array}{c}0.719 \\
(0.449)\end{array}$ & $\begin{array}{l}-0.042 \\
(0.401)\end{array}$ & $\begin{array}{l}-0.054 \\
(0.402)\end{array}$ \\
\hline$\Delta$ Log GDP per Capitat-1 & $\begin{array}{c}0.047 \\
(0.135)\end{array}$ & $\begin{array}{c}4.295 \\
(3.567)\end{array}$ & $\begin{array}{c}4.259 \\
(3.861)\end{array}$ \\
\hline$\Delta$ Unemployment Rate $\mathrm{t}_{-1}$ & $\begin{array}{c}0.006 \\
(0.029)\end{array}$ & $\begin{array}{l}-6.692 \\
(5.696)\end{array}$ & $\begin{array}{l}-6.805 \\
(5.711)\end{array}$ \\
\hline$\Delta$ Income Inequality $_{\mathrm{t}-1}$ & $\begin{array}{c}0.005 \\
(0.014)\end{array}$ & $\begin{array}{c}-0.483 \\
(7.483)\end{array}$ & $\begin{array}{c}-0.139 \\
(7.503)\end{array}$ \\
\hline$\Delta$ Child Mortality Rate $\mathrm{t}_{-1}$ & $\begin{array}{l}-0.266 \\
(2.994)\end{array}$ & & $\begin{array}{c}0.034 \\
(0.043)\end{array}$ \\
\hline \multicolumn{4}{|l|}{ Fixed Pre-Treatment Characteristics as of 1991} \\
\hline GDP per Capita & $\begin{array}{c}60.601 \\
(30.388)\end{array}$ & $\begin{array}{c}-0.022{ }^{* * *} \\
(0.008)\end{array}$ & $\begin{array}{c}-0.023^{* * *} \\
(0.008)\end{array}$ \\
\hline Unemployment Rate & $\begin{array}{c}0.045 \\
(0.023)\end{array}$ & $\begin{array}{c}12.871^{* * *} \\
(5.384)\end{array}$ & $\begin{array}{c}12.790 \text { ** } \\
(5.383)\end{array}$ \\
\hline Income Inequality & $\begin{array}{c}0.452 \\
(0.021)\end{array}$ & $\begin{array}{l}-3.591 \\
(5.820)\end{array}$ & $\begin{array}{c}-3.469 \\
(5.805)\end{array}$ \\
\hline Child Mortality Rate & $\begin{array}{c}6.208 \\
(3.683)\end{array}$ & & $\begin{array}{c}0.009 \\
(0.036)\end{array}$ \\
\hline Population is 5,000 to $25,000(=1)$ & $\begin{array}{c}0.419 \\
(0.493)\end{array}$ & $\begin{array}{c}0.227 \\
(0.472)\end{array}$ & $\begin{array}{c}0.225 \\
(0.480)\end{array}$ \\
\hline Population is 25,000 to $50,000(=1)$ & $\begin{array}{c}0.202 \\
(0.402)\end{array}$ & $\begin{array}{c}0.106 \\
(0.535)\end{array}$ & $\begin{array}{c}0.110 \\
(0.540)\end{array}$ \\
\hline Population is 50,000 to $100,000(=1)$ & $\begin{array}{c}0.114 \\
(0.318)\end{array}$ & $\begin{array}{l}-0.261 \\
(0.605)\end{array}$ & $\begin{array}{l}-0.256 \\
(0.610)\end{array}$ \\
\hline Population is 100,000 to $250,000(=1)$ & $\begin{array}{c}0.079 \\
(0.269)\end{array}$ & $\begin{array}{c}0.663 \\
(0.612)\end{array}$ & $\begin{array}{c}0.668 \\
(0.615)\end{array}$ \\
\hline Population is more than $250,000(=1)$ & $\begin{array}{c}0.066 \\
(0.249)\end{array}$ & $\begin{array}{l}1.159 \text { ** } \\
(0.631)\end{array}$ & $\begin{array}{l}1.151 \text { * } \\
(0.640)\end{array}$ \\
\hline Proportion of Families with Unmet Basic Needs & $\begin{array}{c}0.246 \\
(0.151)\end{array}$ & $\begin{array}{c}-13.660^{* *} \\
(6.067)\end{array}$ & $\begin{array}{c}-13.328 \text { ** } \\
(6.226)\end{array}$ \\
\hline Proportion of Families Living in Overcrowded Housing & $\begin{array}{c}0.097 \\
(0.059)\end{array}$ & $\begin{array}{c}13.560 \text { ** } \\
(7.150)\end{array}$ & $\begin{array}{c}13.444^{\star *} \\
(7.200)\end{array}$ \\
\hline Proportion of Families Living in Poor Housing & $\begin{array}{c}0.060 \\
(0.049)\end{array}$ & $\begin{array}{l}6.980^{* *} \\
(3.472)\end{array}$ & $\begin{array}{c}6.987^{* *} \\
(3.451)\end{array}$ \\
\hline Proportion of Families Living Below Subsistence & $\begin{array}{c}0.036 \\
(0.022)\end{array}$ & $\begin{array}{l}5.2222^{\star *} \\
(7.418)\end{array}$ & $\begin{array}{c}4.917 \\
(7.449)\end{array}$ \\
\hline Proportion of Houses with No Toilet & $\begin{array}{c}0.095 \\
(0.117)\end{array}$ & $\begin{array}{c}10.143^{* *} \\
(4.429)\end{array}$ & $\begin{array}{c}9.798^{* *} \\
(4.563)\end{array}$ \\
\hline No Sewage Connection $(=1)$ & $\begin{array}{c}0.280 \\
(0.449)\end{array}$ & $\begin{array}{l}-0.182 \\
(0.323)\end{array}$ & $\begin{array}{l}-0.171 \\
(0.328)\end{array}$ \\
\hline Proportion Household Heads w/ > High School Education & $\begin{array}{c}0.025 \\
(0.012)\end{array}$ & $\begin{array}{c}-27.242^{* * *} \\
(10.971)\end{array}$ & $\begin{array}{c}-27.182 \text { ** } \\
(11.003)\end{array}$ \\
\hline Mean Household Head's Age btw 45 \& $52(=1)$ & $\begin{array}{c}0.653 \\
(0.476)\end{array}$ & $\begin{array}{l}-0.279 \\
(0.343)\end{array}$ & $\begin{array}{c}0.288 \\
(0.343)\end{array}$ \\
\hline Mean Household Head's Above $52(=1)$ & $\begin{array}{c}0.144 \\
(0.351)\end{array}$ & $\begin{array}{c}0.506 \\
(0.456)\end{array}$ & $\begin{array}{c}0.513 \\
(0.456)\end{array}$ \\
\hline Duration Dependence ${ }^{(b)}$ & & Yes & Yes \\
\hline Number of Observations & 2,281 & 2,281 & 2,281 \\
\hline
\end{tabular}

Notes: (a) Standard errors are in parentheses. ${ }^{* \star *}$ Statistically different from zero at the 0.01 level. ${ }^{* *}$ Statistically different from zero at the 0.05 level. * Statistically different from zero at the 0.1 level. (b) We include a fifth order polynomial in time to control for duration dependence. Each coefficient in the polynomial is statistically different from zero at the 0.01 level. 
Table 4: Comparison of OSN (Public) vs. Aguas Argentinas (Private) Performance, 1980-1999

\begin{tabular}{|c|c|c|c|}
\hline & $\begin{array}{c}\mathrm{OSN}^{(\mathrm{a})} \text { (Before } \\
\text { Privatization) }\end{array}$ & $\begin{array}{l}\text { Aguas Argentinas } \\
\text { (After Privatization) }\end{array}$ & $\begin{array}{c}\Delta \text { After } \\
\text { Privatization }\end{array}$ \\
\hline Water Production (1) (Millions of cubic meters per day) & 3.56 & 3.89 & $9.3 \%$ \\
\hline Spilled Water (2) (Millions of cubic meters per day) & $1.49^{(\mathrm{c})}$ & 1.27 & $-14.8 \%$ \\
\hline Water Supply (1-2) (Millions of cubic meters per day) & $2.07^{(\mathrm{c})}$ & 2.62 & $26.6 \%$ \\
\hline Sewage Drainage Volume (Millions of cubic meters per day) & 2.18 & 2.45 & $12.4 \%$ \\
\hline Water Network Extension (Km of network) & 10,148 & 13,287 & $30.9 \%$ \\
\hline Sewage Network Extension (Km of network) & 6,875 & 8,312 & $20.9 \%$ \\
\hline Average Delay in Attending Repair Requests (Days) & $180^{(d)}$ & $32^{(\mathrm{e})}$ & $-82.2 \%$ \\
\hline Water Leakages Repaired per year & $42,000^{(\mathrm{c})}$ & 96,383 & $129.5 \%$ \\
\hline Sewage Blockages Repaired per year & $100,000^{(c)}$ & 148,500 & $48.5 \%$ \\
\hline Percentage of Clients with Appropriate Water Pressure & $17^{(\mathrm{c})}$ & $54^{(f)}$ & $217.6 \%$ \\
\hline Water Turbidness (Turbidness units) & 7.5 & 2.3 & $-70 \%$ \\
\hline Usage Fee Index ${ }^{(g)}$ & 100 & 84 & $-16 \%$ \\
\hline Employees & 9300 & 4000 & $-57 \%$ \\
\hline
\end{tabular}

Notes: (a) Average for the period 1980-1992. (b) Average for the period 1994-1999. (c) 1993 only. (d) 1992 only. (e) Average excludes 1994. (f) 1996 only. (g) Corresponds to the "K" tariff factor. Source: UADE-CEER.

Table 5: Network Expansion by Income Group in Greater Buenos Aires (1993-2000)

\begin{tabular}{lcc}
\hline \multicolumn{1}{c}{ Income level } & New Connections & Percentage \\
\hline High \& Upper Middle Income & 90,200 & $15.4 \%$ \\
Lower Middle Income & 282,250 & $48.3 \%$ \\
Low Income & 211,800 & $36.3 \%$ \\
Total & 584,250 & $100.0 \%$ \\
\hline
\end{tabular}

Source: Subsecretaría de Recursos Hídricos, from Abdala and Spiller (1999). 
Table 6: Difference-in-Differences Estimates of the Impact of Privatization on the Proportion of Households Connected to the Water Network, 1991-1997

\begin{tabular}{|c|c|c|}
\hline & All municipalities & $\begin{array}{l}\text { Excluding Buenos } \\
\text { Aires }\end{array}$ \\
\hline \multicolumn{3}{|l|}{ Municipalities that were not privatized before 1997: } \\
\hline Proportion of households connected in $1991\left(p_{91}^{\text {public }}\right)$ & 0.866 & 0.866 \\
\hline Proportion of households connected in $1997\left(\mathrm{p}_{97}^{\text {public }}\right)$ & 0.898 & 0.898 \\
\hline Difference $1997-1991\left(\mathrm{p}_{97}^{\text {public }}-\mathrm{p}_{91}^{\text {public }}\right)$ & 0.032 & 0.032 \\
\hline \multicolumn{3}{|l|}{ Municipalities that were privatized before 1997: } \\
\hline Proportion of households connected in $1991\left(\mathrm{p}_{91}^{\text {private }}\right)$ & 0.730 & 0.640 \\
\hline Proportion of households connected in 1997 ( $\left.\mathrm{p}_{97}^{\text {private }}\right)$ & 0.780 & 0.714 \\
\hline Difference $1997-1991\left(\mathrm{p}_{97}^{\text {private }}-\mathrm{p}_{91}^{\text {private }}\right)$ & 0.050 & 0.074 \\
\hline Difference in-Differences $\left(p_{97}^{\text {private }}-p_{91}^{\text {private }}\right)-\left(p_{97}^{\text {public }}-p_{91}^{\text {public }}\right)$ & 0.018 & 0.042 \\
\hline Z-test for Difference-in-Differences Estimate ${ }^{(a)}$ & $2.83^{* * *}$ & $5.78^{* \star *}$ \\
\hline
\end{tabular}

Notes: The pre-intervention connection rates are higher in control areas than in treatment areas in this table. However, this analysis only takes into account privatization through 1996 and, therefore, the control group includes the set of municipalities that privatized later. When all of the privatized municipalities are included in the treatment group, the pre-privatization connection rates are the same in (eventually) treated and control groups (see Galiani et al, 2002). Specifically, in 1991, 74 percent of households were connected in eventually privatized areas and 70 in never privatized areas. (a) The statistic of contrast is $\mathrm{z}=\frac{\left(\mathrm{p}_{97}^{\text {private }}-\mathrm{p}_{91}^{\text {private }}\right)-\left(\mathrm{p}_{97}^{\text {public }}-\mathrm{p}_{91}^{\text {public }}\right)}{\sqrt{\frac{\mathrm{p}_{97}^{\text {private }}\left(1-\mathrm{p}_{97}^{\text {private }}\right)}{\mathrm{n}_{97}^{\text {public }}}+\frac{\mathrm{p}_{97}^{\text {public }}\left(1-\mathrm{p}_{97}^{\text {public }}\right)}{\mathrm{n}_{97}^{\text {public }}}}}$, where $\mathrm{p}_{\mathrm{t}}$ is the proportion of households with access to water connection in year $t$ in a municipality where water has been privatized (private) or has not been privatized (public), and $n$ is the number of observations. Note that there is no sample variability when we estimate $\mathrm{p}$ for 1991 since these statistics are estimated from Census data. ${ }^{\star \star \star}$ Statistically different from zero at the 0.01 level of significance. 
Table 7: Share of Households Connected to Water and Sewage in 1992 and in 2002 by Income Quintile

\begin{tabular}{|c|c|c|c|c|c|c|}
\hline & \multirow[t]{2}{*}{ All } & \multicolumn{5}{|c|}{ Income Quintile } \\
\hline & & Poorest & $\|$ & III & IV & Wealthiest \\
\hline \multicolumn{7}{|c|}{ Share of Households Connected to Water } \\
\hline 1992 & 0.74 & 0.61 & 0.71 & 0.75 & 0.77 & 0.83 \\
\hline 2002 & 0.88 & 0.82 & 0.85 & 0.88 & 0.92 & 0.91 \\
\hline Change 1992-2002 & +0.14 & +0.21 & +0.14 & +0.13 & +0.15 & +0.09 \\
\hline \multicolumn{7}{|l|}{ Sewage } \\
\hline 1992 & 0.54 & 0.35 & 0.47 & 0.51 & 0.56 & 0.74 \\
\hline 2002 & 0.64 & 0.51 & 0.57 & 0.60 & 0.68 & 0.79 \\
\hline Change 1992-2002 & +0.10 & +0.16 & +0.10 & +0.09 & +0.12 & +0.05 \\
\hline
\end{tabular}

Source: World Bank (2002b). 
Table 8: Difference-in-Differences Estimates of the Impact of Water Services Privatization on Child Mortality (a)

\begin{tabular}{|c|c|c|c|c|c|c|c|}
\hline & \multicolumn{3}{|c|}{ Full Sample } & \multicolumn{3}{|c|}{ Using Observations on Common Support } & \multirow{2}{*}{$\begin{array}{l}\begin{array}{l}\text { Kernal Density Matched } \\
\text { on Common Support }\end{array} \\
\text { (7) }\end{array}$} \\
\hline & (1) & (2) & (3) & (4) & (5) & (6) & \\
\hline Private Water Services $(=1)$ & $\begin{array}{l}-0.334 * * \\
(0.169)\end{array}$ & $\begin{array}{c}-0.320 * \\
(0.170)\end{array}$ & $\begin{array}{l}-0.283^{*} \\
(0.170)\end{array}$ & $\begin{array}{l}-0.540^{* \star *} \\
(0.177)\end{array}$ & $\begin{array}{l}-0.541^{* * *} \\
(0.178)\end{array}$ & $\begin{array}{l}-0.525^{* * *} \\
(0.178)\end{array}$ & $\begin{array}{l}-0.604^{* * *} \\
(0.168)\end{array}$ \\
\hline $\begin{array}{l}\% \Delta \text { in Mortality Rate } \\
\text { Other Covariates: }\end{array}$ & $-5.3 \%$ & $-5.1 \%$ & $-4.5 \%$ & $-8.6 \%$ & $-8.6 \%$ & $-8.4 \%$ & $-10.0 \%$ \\
\hline Real GDP per capita & & $\begin{array}{c}0.007 \\
(0.005)\end{array}$ & $\begin{array}{c}0.009 \\
(0.006)\end{array}$ & & $\begin{array}{c}0.005 \\
(0.006)\end{array}$ & $\begin{array}{l}0.006 \\
(0.006)\end{array}$ & \\
\hline Unemployment Rate & & $\begin{array}{l}-0.555 \\
(1.757)\end{array}$ & $\begin{array}{l}-0.636 \\
(1.758)\end{array}$ & & $\begin{array}{l}-0.778 \\
(1.797)\end{array}$ & $\begin{array}{l}-0.836 \\
(1.802)\end{array}$ & \\
\hline Income Inequality & & $\begin{array}{l}5.171^{*} \\
(2.868)\end{array}$ & $\begin{array}{l}5.085^{*} \\
(2.880)\end{array}$ & & $\begin{array}{c}3.052 \\
(2.926)\end{array}$ & $\begin{array}{c}3.052 \\
(2.926)\end{array}$ & \\
\hline $\begin{array}{l}\text { Public Spending per } \\
\text { Capita }\end{array}$ & & $\begin{array}{l}-0.028 \\
(0.038)\end{array}$ & $\begin{array}{l}-0.035 \\
(0.038)\end{array}$ & & $\begin{array}{l}-0.068^{*} \\
(0.039)\end{array}$ & $\begin{array}{r}-0.07^{*} \\
(0.039)\end{array}$ & \\
\hline $\begin{array}{l}\text { Local Government by } \\
\text { Radical Party }(=1)\end{array}$ & & & $\begin{array}{l}0.482^{*} \\
(0.267)\end{array}$ & & & $\begin{array}{c}0.166 \\
(0.284)\end{array}$ & \\
\hline $\begin{array}{l}\text { Local Government by } \\
\text { Peronist Party }(=1)\end{array}$ & & & $\begin{array}{l}-0.202 \\
(0.191)\end{array}$ & & & $\begin{array}{l}-0.168 \\
(0.193)\end{array}$ & \\
\hline $\begin{array}{l}\text { F-Stat for joint significance of } \\
\text { Municipality Fixed Effects }\end{array}$ & $13.84^{\star \star \star}$ & $11.70^{\star * \star}$ & $11.51^{* \star *}$ & $10.39^{* \star *}$ & $8.56^{* \star *}$ & $8.32^{* \star *}$ & \\
\hline $\begin{array}{l}\text { F-Stat for joint significance of } \\
\text { Year Fixed Effects }\end{array}$ & $55.03^{* \star *}$ & $17.57^{* * *}$ & $18.25^{* * *}$ & $52.25^{\star \star *}$ & $12.76^{* \star *}$ & $12.98^{* * *}$ & \\
\hline $\begin{array}{l}\text { Hausman Test Statistic for } \\
\text { Municipality Random Effect }\end{array}$ & 3.64 & $68.20^{\star \star *}$ & $81.87^{* \star *}$ & 9.15 & $57.48^{* \star *}$ & $65.04^{\star * \star}$ & \\
\hline R-Squared & 0.1227 & 0.1254 & 0.1272 & 0.1390 & 0.1408 & 0.1420 & \\
\hline Number of Observations & 4732 & 4597 & 4597 & 3970 & 3870 & 3870 & 3970 \\
\hline
\end{tabular}

Notes: (a) Each column reports the estimated coefficients and standard errors of a separate regression model where the dependent variable is the child mortality rate and whose mean was $6.25 \%$ in 1990 . All of the regressions include year and municipality fixed effects. ${ }^{* \star}$ Statistically different from zero at the 0.01 level of significance. ${ }^{* \star}$ Statistically different from zero at the 0.05 level of significance. * Statistically different from zero at the 0.1 level of significance. (b) The standard errors for the Kernel Weighted Matching Estimate are bootstrapped standard errors using 100 replications. 
Table 9: Difference-in-Differences Estimates of the Impact of Privatization by Cause of Death

\begin{tabular}{|c|c|c|c|}
\hline & $\begin{array}{c}1990 \text { Mean } \\
\text { Mortality } \\
\text { Rate }\end{array}$ & $\begin{array}{c}\text { Estimated Impact Coefficient \& } \\
\text { Standard Error }\end{array}$ & $\begin{array}{c}\% \Delta \text { in Mortality } \\
\text { Rate }\end{array}$ \\
\hline Infectious and Parasitic Diseases & 0.565 & $\begin{array}{c}-0.103^{* *} \\
(0.048)\end{array}$ & $-18.2 \%$ \\
\hline Perinatal Deaths & 2.316 & $\begin{array}{c}-0.266^{* *} \\
(0.105)\end{array}$ & $-11.5 \%$ \\
\hline All Other Causes in Aggregate & 2.565 & $\begin{array}{c}0.082 \\
(0.114)\end{array}$ & $\cdots \cdots$ \\
\hline \multicolumn{4}{|l|}{ All Other Causes Disaggregated: } \\
\hline Accidents & 0.399 & $\begin{array}{l}-0.004 \\
(0.057)\end{array}$ & $\cdots$ \\
\hline Congenital Anomalies & 0.711 & $\begin{array}{l}-0.022 \\
(0.056)\end{array}$ & $\cdots \cdot$ \\
\hline Skin and Soft Tissues Diseases & 0.000 & $\begin{array}{l}0.000 \\
(0.001)\end{array}$ & $\cdots \cdots$ \\
\hline Blood and Hematologic Diseases & 0.024 & $\begin{array}{l}-0.002 \\
(0.008)\end{array}$ & -.... \\
\hline Nervous System Disorders & 0.163 & $\begin{array}{c}0.025 \\
(0.026)\end{array}$ & $\cdots \cdots$ \\
\hline Cardiovascular Diseases & 0.236 & $\begin{array}{l}0.006 \\
(0.030)\end{array}$ & $\cdots .$. \\
\hline Gastrointestinal Tract Disorders & 0.051 & $\begin{array}{l}-0.001 \\
(0.010)\end{array}$ & $\cdots \cdots$ \\
\hline Genital and Urinary Diseases & 0.020 & $\begin{array}{l}-0.006 \\
(0.007)\end{array}$ & $\cdots \cdots$ \\
\hline $\begin{array}{l}\text { Osteoarticular and Connective } \\
\text { Tissue Diseases }\end{array}$ & 0.003 & $\begin{array}{l}-0.001 \\
(0.001)\end{array}$ & $\cdots$ \\
\hline Respiratory Diseases & 0.511 & $\begin{array}{l}-0.038 \\
(0.051)\end{array}$ & $\cdots \cdots$ \\
\hline $\begin{array}{l}\text { Immuno-deficiencies, Endocrine and } \\
\text { Nutrition System Diseases }\end{array}$ & 0.376 & $\begin{array}{l}-0.035 \\
(0.033)\end{array}$ & $\cdots$ \\
\hline Mental Disorders & 0.002 & $\begin{array}{c}0.001 \\
(0.001)\end{array}$ & $\cdots \cdots$ \\
\hline Tumors & 0.068 & $\begin{array}{l}-0.006 \\
(0.015)\end{array}$ & $\cdots \cdots$ \\
\hline
\end{tabular}

Notes: Each cell reports the estimated coefficient (and standard error) on the Private Water Services dummy from a different difference-in-difference regression. All of the regressions include year and municipality fixed effects, and the socioeconomic and political covariates included in the regression reported in Column 6 of Table 8. All of the regressions use only the 3870 observations on the common support. ${ }^{* \star *}$ Statistically different from zero at the 0.01 level of significance. ${ }^{* *}$ Statistically different from zero at the 0.05 level of significance. * Statistically different from zero at the 0.1 level of significance. 
Table 10: Difference-in-Differences Estimates of the Impact of Privatization by Poverty Level

\begin{tabular}{cccc}
\hline & $\begin{array}{c}\text { 1990 Mean } \\
\text { Mortality Rate }\end{array}$ & $\begin{array}{c}\text { Estimated Impact Coefficient } \\
\text { \& Standard Error }\end{array}$ & $\begin{array}{c}\% \Delta \text { in Mortality } \\
\text { Rate }\end{array}$ \\
\hline Non-poor Municipalities & 5.07 & $\begin{array}{c}0.114 \\
(0.233)\end{array}$ & $\ldots .$. \\
Poor Municipalities & 6.97 & $\begin{array}{c}-1.004^{* * *} \\
(0.279)\end{array}$ & $-14.4 \%$ \\
& & $\begin{array}{c}-2.415^{* * *} \\
(0.544)\end{array}$ & $-26.5 \%$
\end{tabular}

Notes: Municipalities are divided into poverty groups using the government's index of Unmet Basic Needs (UBN) using data from the 1991 Census. Non-poor municipalities are defined as those in which less than $25 \%$ of households have Unmet Basic Needs. Poor municipalities are defined as those in which $25 \%$ to 50 $\%$ of households have Unmet Basic Needs. Extremely poor municipalities are defined as those in which more than $50 \%$ of households have Unmet Basic Needs. The reported coefficients are the interaction of the Private Water Services dummy and UBN (recoded in a set of dummy variables in the following categories: below $25 \%$, between $25 \%$ and $50 \%$, and above $50 \%$ ) in a difference-in-differences regression using only the 3870 observations on the common support. The regression also includes year and municipality fixed effects, and the socioeconomic and political covariates included in the regression reported in Column 6 of Table 8. Standard errors are reported in parentheses. ${ }^{* \star \star}$ Statistically different from zero at the 0.01 level of significance. ${ }^{* *}$ Statistically different from zero at the 0.05 level of significance. * Statistically different from zero at the 0.1 level of significance. 


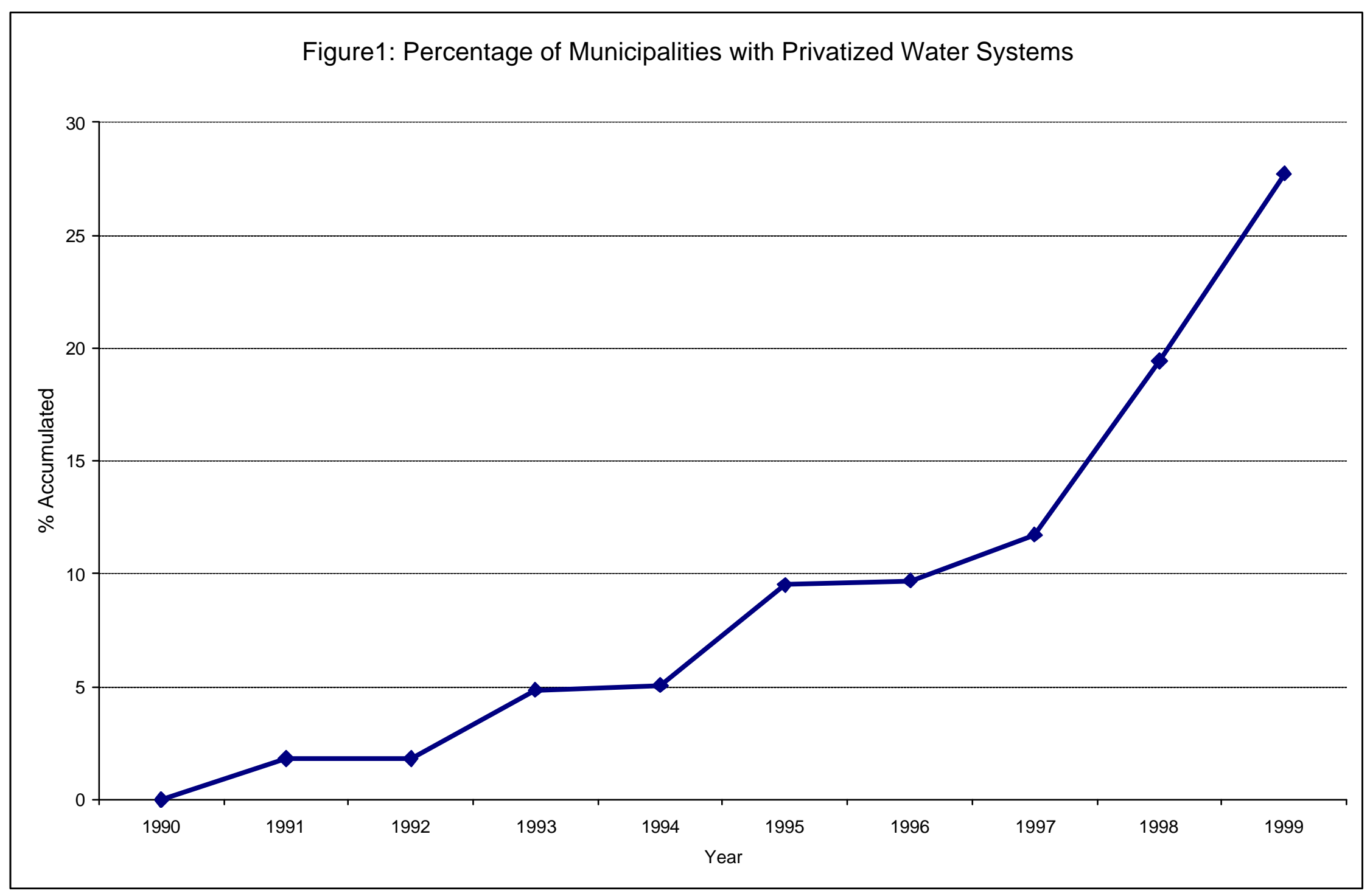




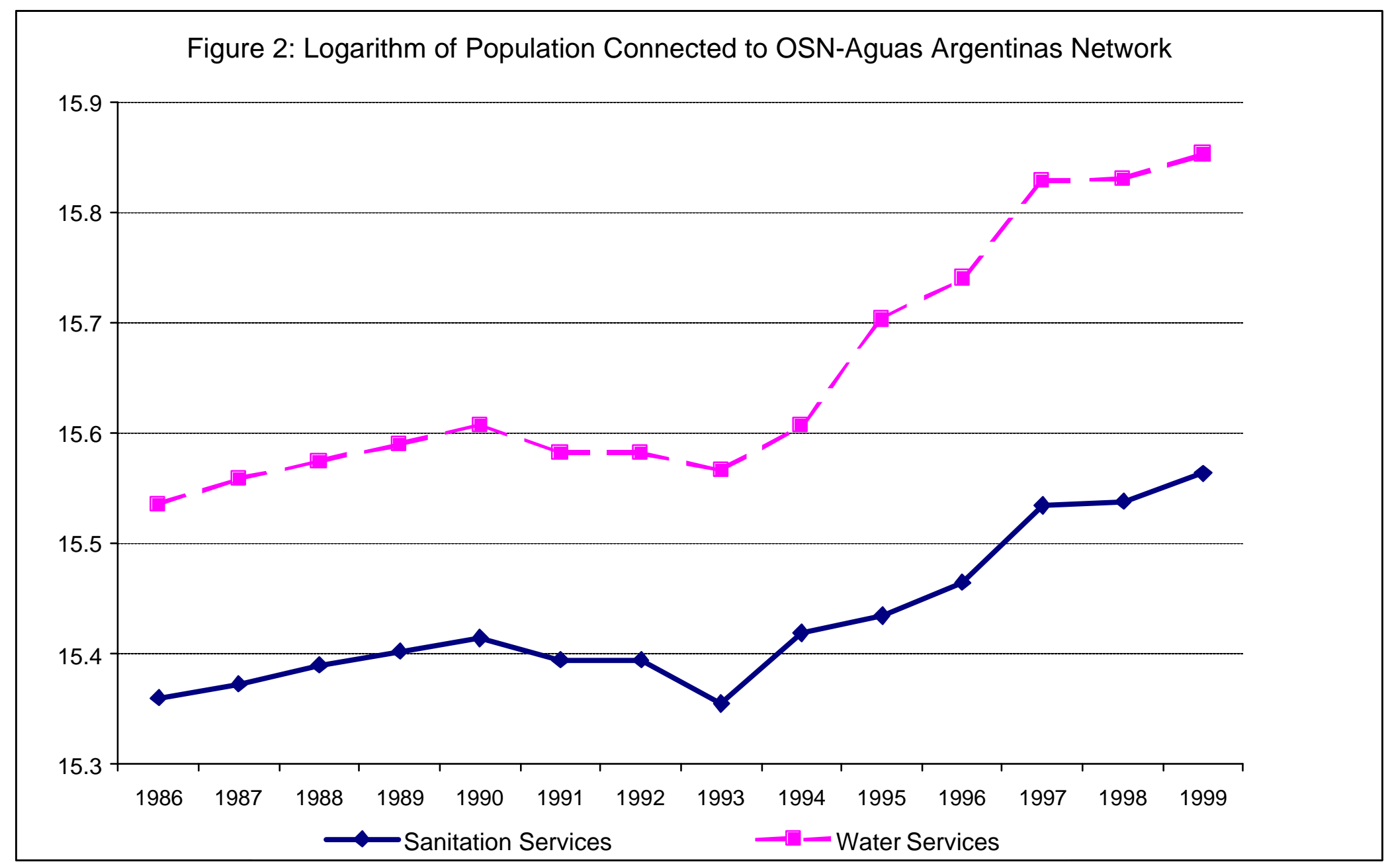




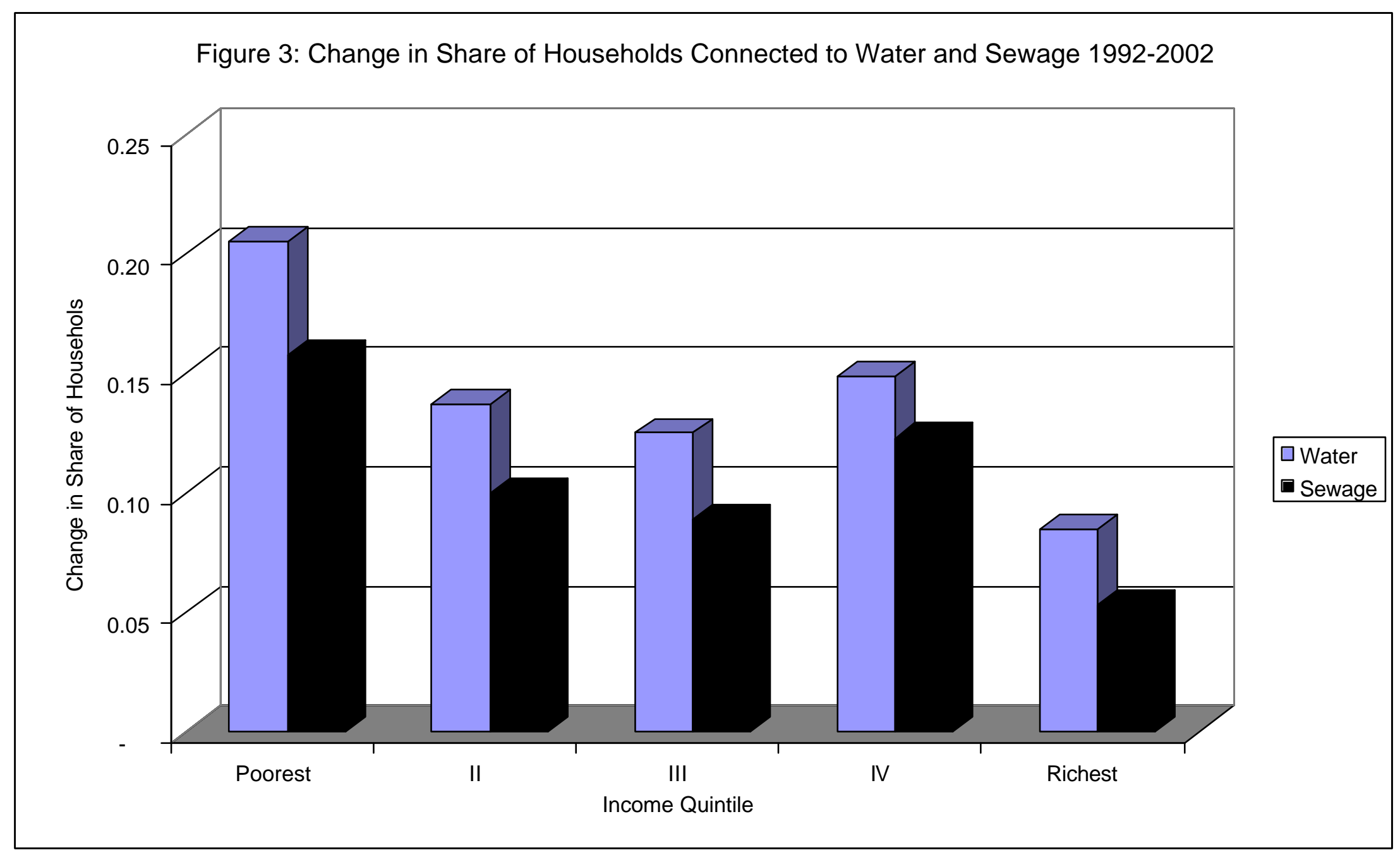


Figure 4: Evolution of Mortality Rates for Municipalities with Privatized vs. Non-Privatized Water Services

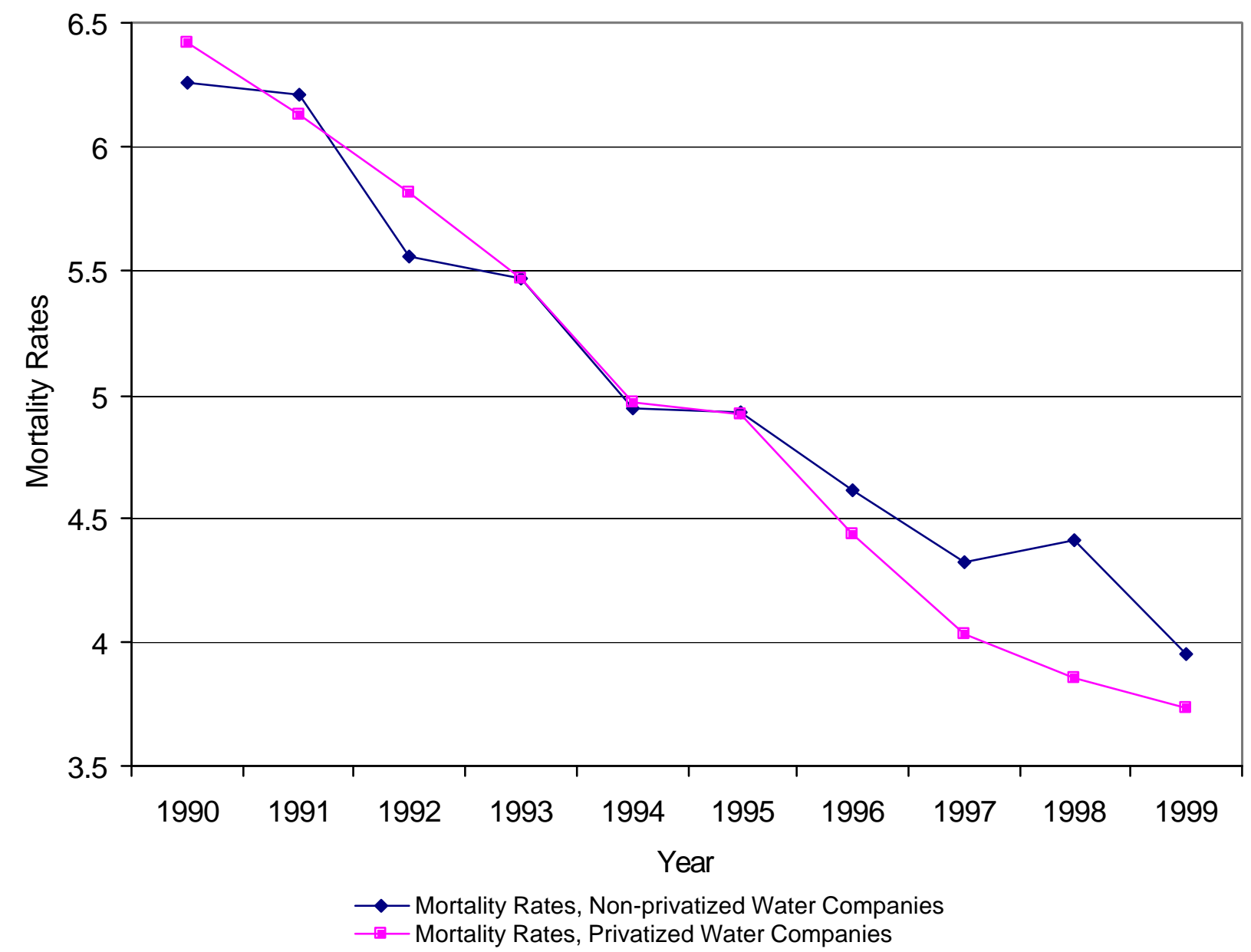

